\begin{tabular}{|l|l|}
\hline $\begin{array}{l}\text { 2. To: (Receiving Organization) } \\
\text { Project Development/Implementaton }\end{array}$ & $\begin{array}{l}\text { 3. From: (Originating Organization) } \\
\text { Project Definition }\end{array}$ \\
\hline $\begin{array}{l}\text { 5. Proj./Prog./Dept./Div: } \\
\text { TWRS }\end{array}$ & $\begin{array}{l}\text { 6. Design Authority/Design Agent/Cog. Engr.: } \\
\text { Thomas H. May }\end{array}$ \\
\hline $\begin{array}{l}\text { 8. Originator Remarks: } \\
\text { Please review and approve the attached Assessment of the Electrical } \\
\text { Power Requirements Continued Safe Storage and Waste Feed Delivery } \\
\text { Support (SST/DST). }\end{array}$
\end{tabular}

11. Receiver Remarks:

11A. Design Baseline Document? $O$ Yes

No
4. Related EDT No.:
N/A
$\begin{aligned} & \text { 7. Purchase Order No:: } \\ & \text { N/A }\end{aligned}$

9. Equip./Component No.:

$\mathrm{N} / \mathrm{A}$

10. System/BIdg./Facility:

DST Electrical Dist

12. Major Assm. Dwg. No.:

13. Permit/Permit Application No.:

$\mathrm{N} / \mathrm{A}$

14. Required Response Date:

$1 / 13 / 00$

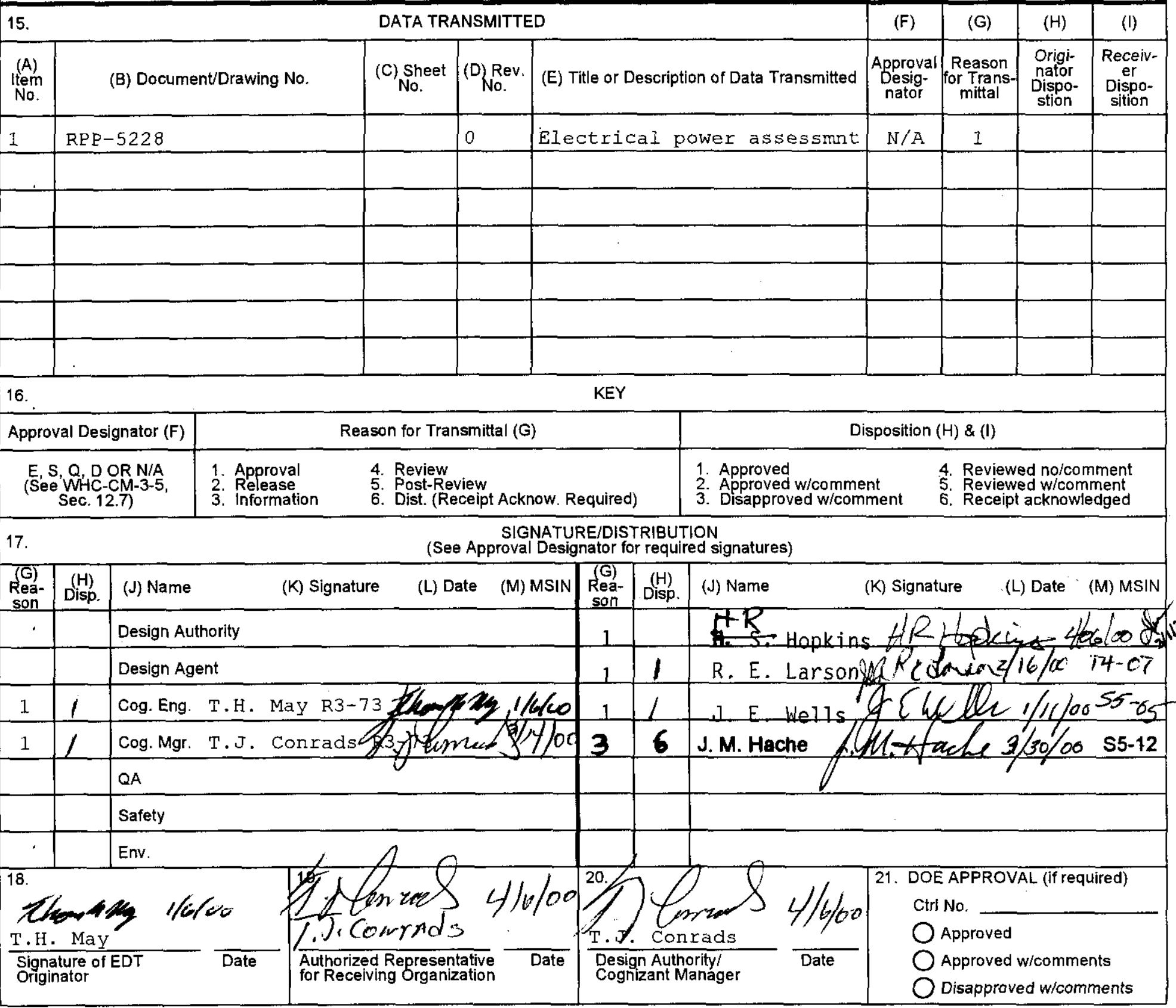




\title{
Assessment of the Electrical Power Requirements for Continued Safe Storage and Waste Feed Delivery Phase One
}

\author{
Thomas H. May \\ CH2MHILL Hanford Group \\ Richland, WA 99352 \\ U.S. Department of Energy Contract DE-AC06-96RL13200
EDT/ECN: $628254 \quad$ UC: $N / A$
Org Code: UF130000 Charge Code: 110299 \\ B\&R Code: N/A Total Pages: 53
}

Key Words: Electricity, power distribution

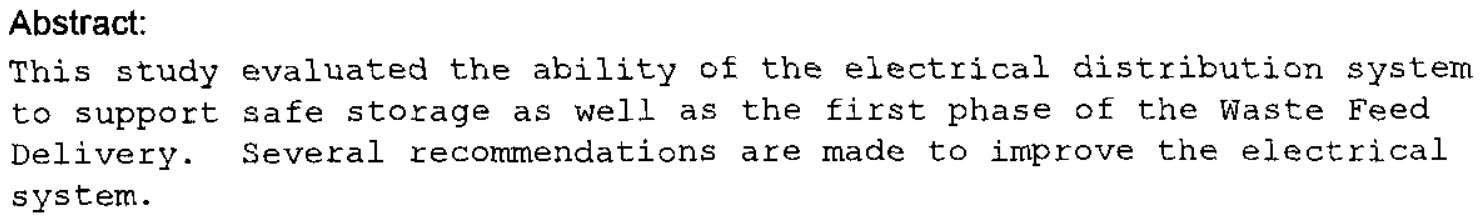

TRADEMARK DISCLAIMER. Reference herein to any specific commercial product, process, or service by trade name, trademark, manufacturer, or otherwise, does not necessarily constitute or imply its endorsement, recommendation, or favoring by the United States Government or any agency thereof or its contractors or subcontractors.

Printed in the United States of America. To obtain copies of this document, contact: Document Control Services, P.O. Box 950, Mailstop H6-08, Richland WA 99352, Phone (509) 372-2420; Fax (509) 376-4989.
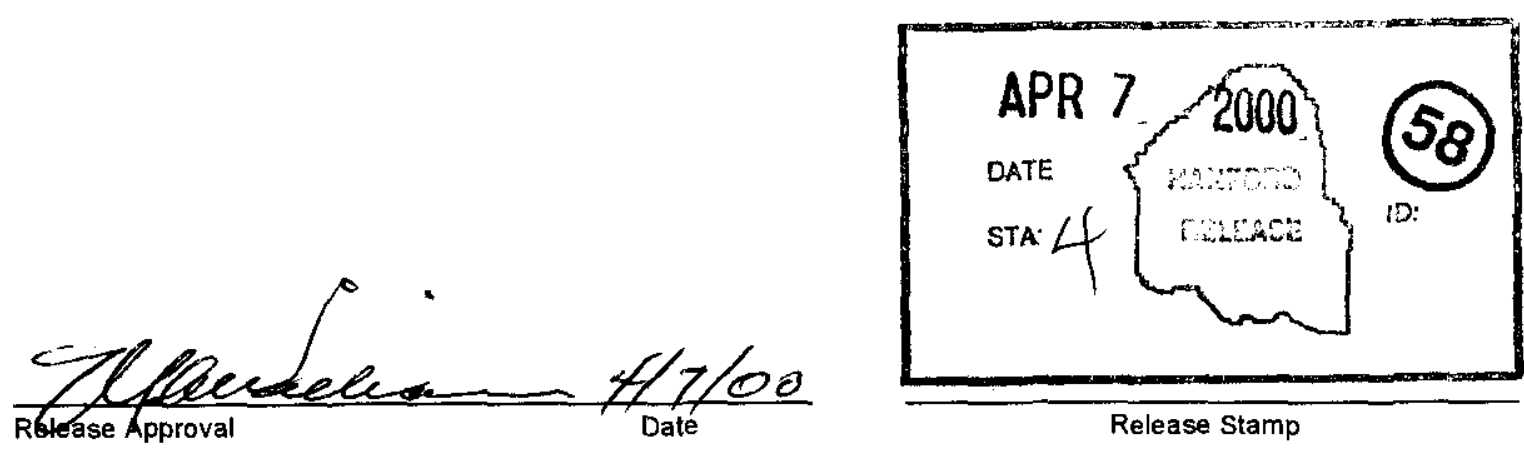

Release Stamp 
RPP-5228

REVISION 0

\title{
ASSESSMENT OF THE ELECTRICAL POWER REQUIREMENTS FOR CONTINUED SAFE STORAGE AND WASTE FEED DELIVERY PHASE ONE
}

January 2000

\author{
T. H. May \\ CH2MHILL Hanford GROUP \\ Richland, Washington \\ R. L. Golberg \\ ARES Corporation \\ Richland, Washington \\ Prepared for: \\ Office of River Protection \\ Richland, Washington
}


RPP-5228

REVISION 0

This page intentionally left blank. 
REVISION 0

\section{TABLE OF CONTENTS}

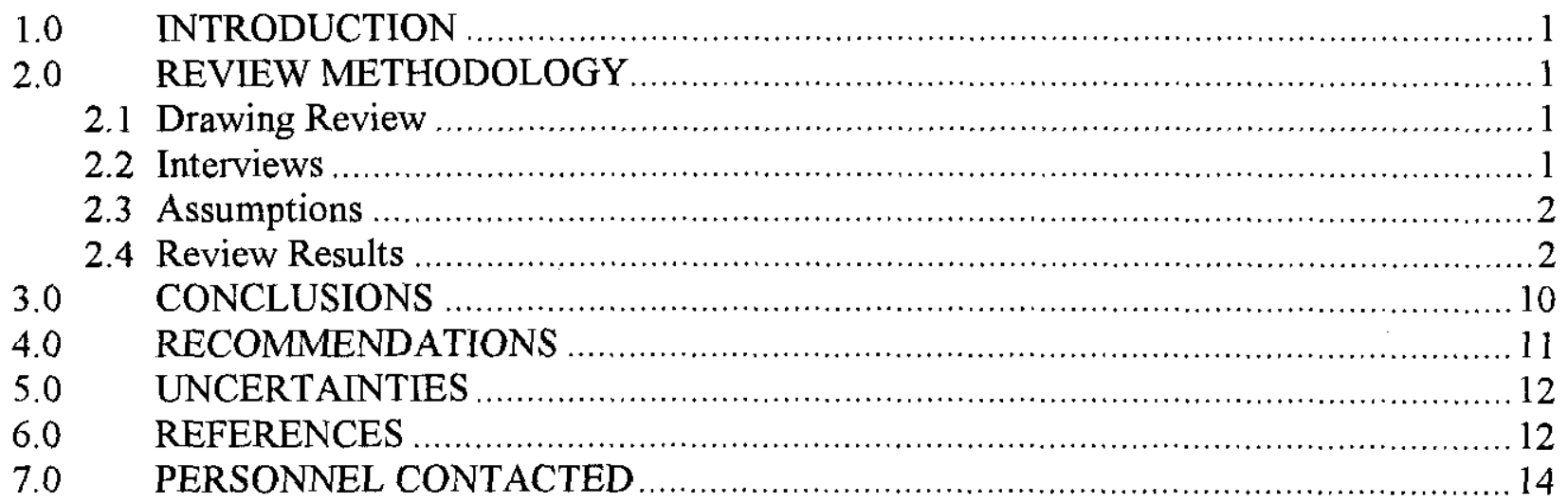

\section{APPENDICES}

Appendix A

East Area Transformer Locations

Appendix B

Electricity Consumption and Cost Reports

Appendix C

Scope of Work 


\section{RPP-5228 \\ REVISION 0}

\section{TABLES}

Table 2.1. Electrical Load Data for DSTs.

Table 2.2. Single-Shell Tank Farms Power Requirements 


\section{RPP-5228}

REVISION 0

\section{ACRONYMS}

$\begin{array}{ll}\text { ANSI } & \text { American National Standard Institute } \\ \text { DST } & \text { Double-shell tank } \\ \text { ECN } & \text { Engineering Change Notice } \\ \text { HVAC } & \text { Heating, Ventilation, and Air Conditioning } \\ \text { IEEE } & \text { Institute of Electrical and Electronics Engineering } \\ \text { LMHC } & \text { Lockheed Martin Hanford Corporation } \\ \text { MCC } & \text { Motor Control Center } \\ \text { NEC } & \text { National Electric Code } \\ \text { SST } & \text { Single-shell tank } \\ \text { TWRSO\&UP } & \text { Tank Waste Remediation System Operations and Utilization Plan } \\ \text { WFD } & \text { Waste Feed Delivery } \\ \text { WRF } & \text { Waste Retrieval Facilities }\end{array}$




\section{ASSESSMENT OF THE ELECTRICAL POWER REQUIREMENTS FOR CONTINUED SAFE STORAGE AND WASTE FEED DELIVERY (SSTs/DSTs)}

\subsection{INTRODUCTION}

The ability to assure adequate Waste Feed Delivery (WFD) to the Privatization Contractor's vitrification facility is a key element in the overall Hanford cleanup schedule. An important aspect of this WFD is the availability of sufficient and appropriate electrical power in the single- and double-shell tank farms.

The methodology for performing this review and the results are described below.

\section{2,0 REVIEW METHODOLOGY}

This study reviewed the ability of the existing $13.8 \mathrm{kVA}$ transformers to support WFD. Existing power demands were estimated from metered loads with a 125 percent factor [NEC $220-35$ (2)]. This study does not provide calculations for acceptability of secondary electrical systems.

The review methodology used for preparing this assessment was to first review the Tank Waste Remediation System Operations and Utilization Plan (TWRSO\&UP) HNF-SD-WM-SP012 to determine the mission of the WFD and then to review the available drawings to determine the current electrical configuration in place at each facility. Interviews were then held with key people to determine the current planning regarding operations and future modifications and to incorporate the results of these interviews with the WFD documentation to summarize future requirements. Finally, the requirements were compared to the existing/planned installations and recommendations were developed. Details of the drawing reviews/interviews and resulting recommendations are shown below.

\subsection{Drawing Review}

Copies of the latest one-line drawings for each single-shell and double-shell tank farm, electrical utility switching diagrams and distribution maps were obtained from microfilm. Copies of the latest Engineering Change Notices (ECNs) were also used for reviewing the DST farm one-line drawings.

\subsection{Interviews}

Lockheed Martin Hanford Corporation (LMHC) Electrical Engineers for the DST farms were contacted to obtain information on the present and future requirements for safe storage. The Electrical Engineer for Project W-211, "Initial Tank Retrieval System," was also contacted 


\section{RPP-5228 \\ REVISION 0}

to obtain information on the mixer pumps, transfer pumps, and caustic/diluent systems which Project W-211 are planning to install in the AN, AP, AY, AZ, and SY Tank Farms. Project W521 will also install similar mixer pumps, transfer pumps, and caustic/diluent system installations in additional tanks in the AN, AW, AY, AZ and SY Tank Farms. The DynCorp Electrical Engineer was contacted for utility metering information and $13.8 \mathrm{kV}$ line loading information. Engineers from Project W-314, "Tank Farm Restoration and Safe Operation," were contacted for information on the proposed ventilation upgrades to the AN, AP, AW, and SY Tank Farms.

\subsection{Assumptions}

The power required for safe storage and retrieval/transfer of waste in the double-shell and single-shell tank farms was determined by identifying the maximum electrical demand power reading obtained from utility metering over a two year period for each DST farm. The results are shown in Table 2.1. The results are based on the following assumptions:

- The hot water heaters/boilers for the 200 East Tank Farms will be combustionfired and not electrical like the SY Tank Farm units, as the additional electrical load on line C8-L6 would exceed the line capacity.

- $\quad$ The caustic/diluent flush system electrical power requirements for the new systems will be similar to the design of Project W-211 for the AZ Tank Farm (100 kVA). Caustic/diluent systems are only planned for the AW and AZ Tank Farms.

- The construction power for the Privatization Contractor's facility will be fed from the $13.8 \mathrm{kV}$ line C8-L5 and will not impact the anticipated loads for the tank farms.

- $\quad$ The power for the Cross-Site Transfer Line booster pump is fed from a transformer installed for the booster pump station and will not impact the loads for the tank farm transformers.

- $\quad$ All new pump loads will be running at the maximum horsepower (100 percent load).

- The electrical loads projected by Project W-314 for the Heating, Ventilation, and Air Conditioning (HVAC) upgrades in the AN, AP, AW, and SY Tank Farms will be equal to or less than the existing electrical HVAC loads.

- All electrical loads will operate with a 0.8 power factor (where appropriate).

\subsection{Review Results}

The specific elements of the review and the results are discussed below.

- $\quad$ Assessment Item \#1 - Assess the electrical power required for continued safe storage of waste in the DSTs. 


\section{RPP-5228 \\ REVISION 0}

The existing transformers are sufficient to provide power to support safe storage of waste in the DSTs for the AN, AP, AW, AY, and AZ Tank Farms (See Appendix A for locations). The transformer capacity for the SY Tank Farm needs to be increased immediately as the loads include two $500 \mathrm{~kW}$ water heaters. The $500 \mathrm{~kW}$ heaters were used on an "as needed" basis, but with additional hot water required for saltwell pumping, cross-site transfers, and the transfer from tank SY101 to tank SY-102, the heaters are needed as a continuous load. This puts an excessive load on the two $500 \mathrm{kVA}$ substation transformers. A new 100-hp. transfer pump was also added for the transfer of waste from tank SY-101 to tank $\mathrm{SY}-102$. One of the existing $500 \mathrm{~kW}$ heaters is now being temporarily refed from a bank of three pole mounted $167 \mathrm{kVA}$ transformers $(500 \mathrm{kVA})$ to avoid an additional overload on one of the existing SY $500 \mathrm{kVA}$ transformers after the addition of the 100-hp. transfer pump.

The loads for the AZ Tank Farm and AY-101 include the existing annulus exhaust fans and heaters for tanks AZ-101, AZ-102, and AY-101. These systems have been shut down for maintenance and future upgrades. The anticipated additional loads on the $A Z$ transformer when these systems are returned to operation would be approximately $70 \mathrm{kVA}$ and $30 \mathrm{kVA}$ on the A Tank Farm transformer.

- Assessment Item \#2 - Assess the electrical power required to retrieve waste from the DSTs for Phase 1 WFD, based on the assumption that there would be two 300-hp. mixer pumps operating simultaneously and a concurrent transfer of waste by a 60-hp. transfer pump per tank farm. The power loads will also include estimates of additional power required for support systems.

The existing $1000 \mathrm{kVA}$ transformers in the AN, AP, and AZ Tank Farms have the capacity to handle the additional load of $663 \mathrm{kVA}$ required for the full load capacity of two 300-hp. mixer pumps and a 60-hp. transfer pump. The addition of the Caustic and Diluent Addition System with a projected $100 \mathrm{kVA}$ load for the AN and AW Tank Farms will not cause any significant change in the transformer capacity. Electric hot water heaters were not addressed in the requirements for the 200 East Tank Farm.

This conclusion is based on the existing peak demand loads (Appendix B) recorded over a two-year period with a 125 percent demand to allow for small loads [NEC 220-35 (2)], as shown in Table 2.1. The transformers are also capable of carrying additional loads based on the loading guidance in American National Standard Institute (ANSI) C57.91 for oil-filled transformers. 


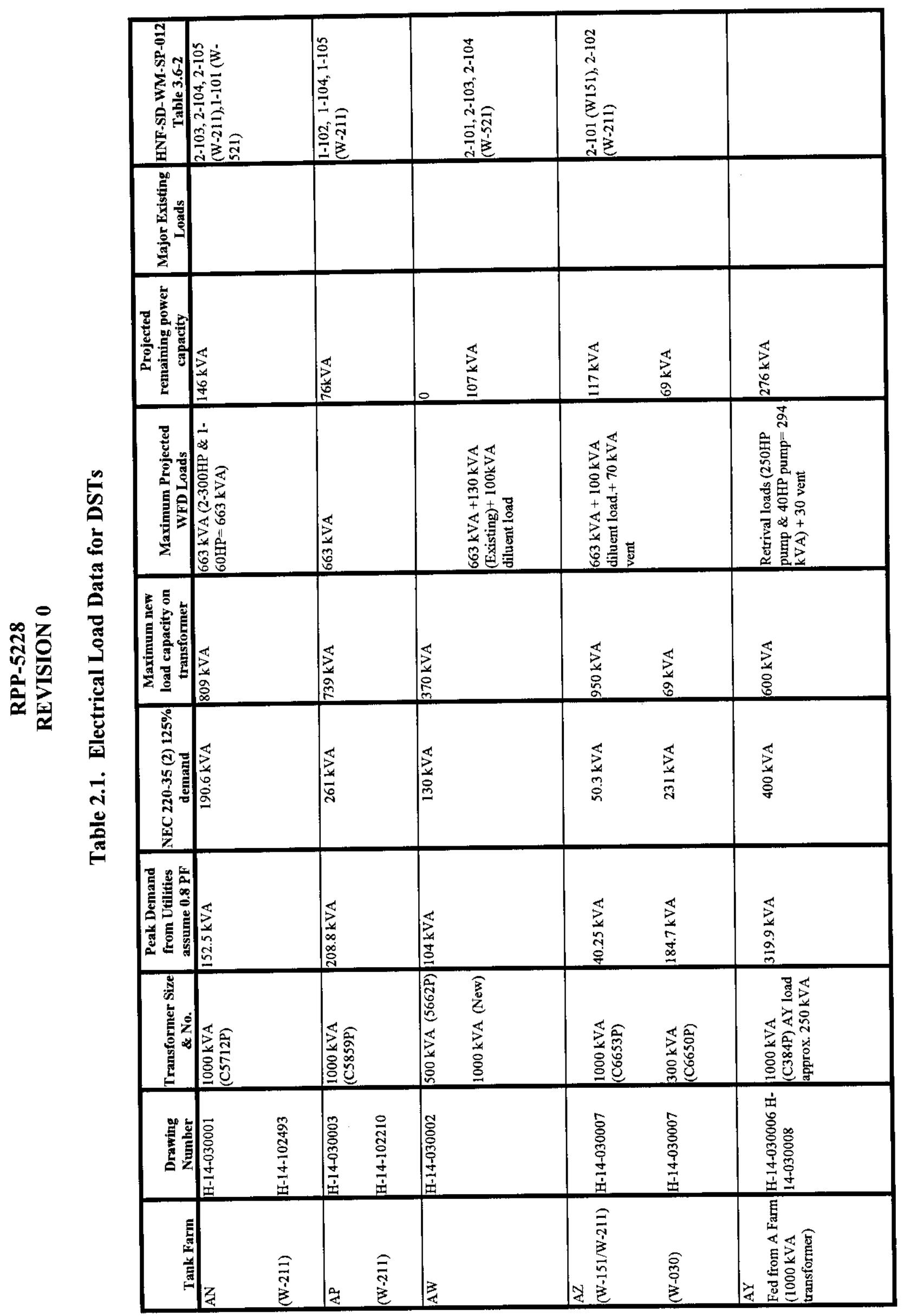




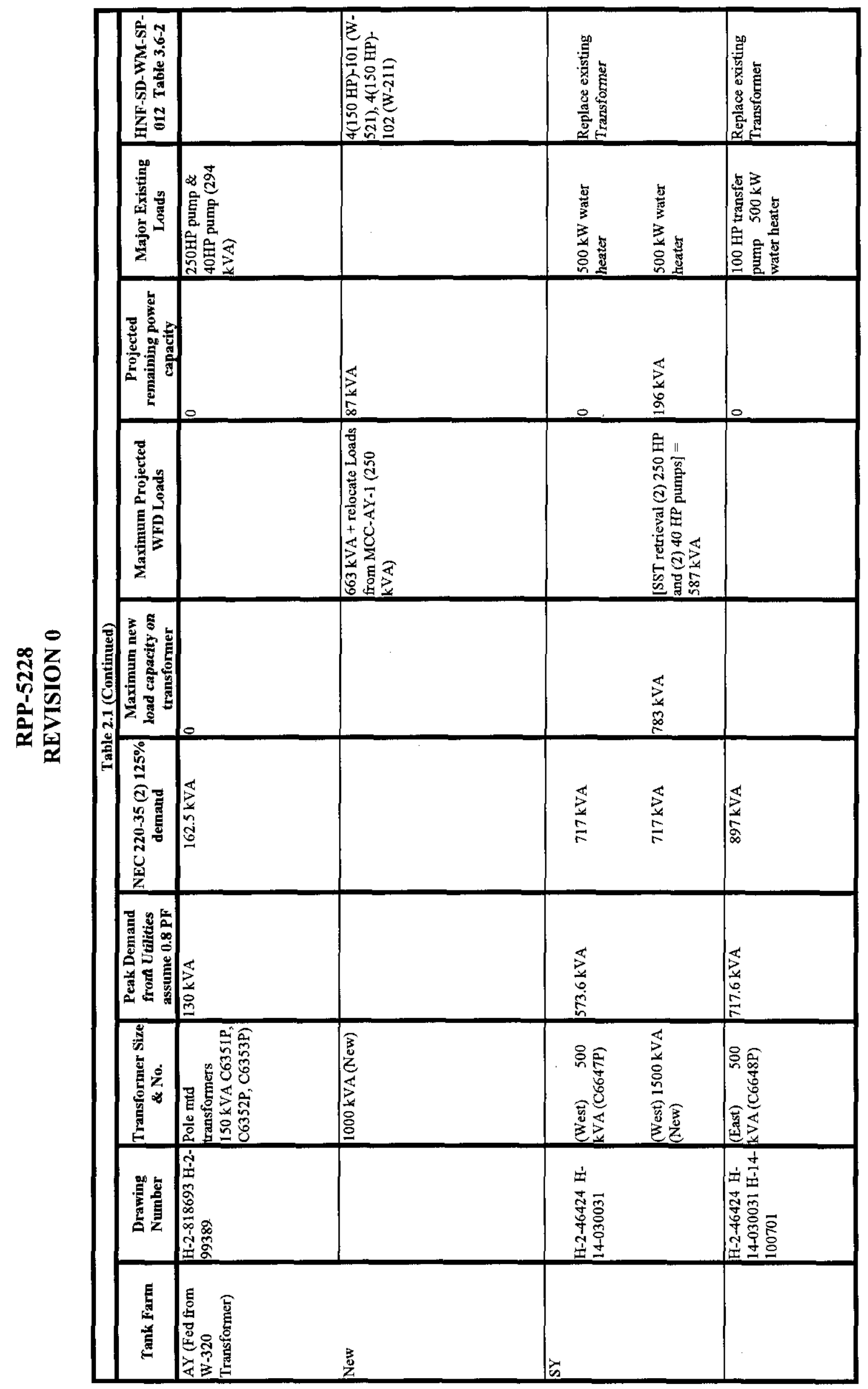




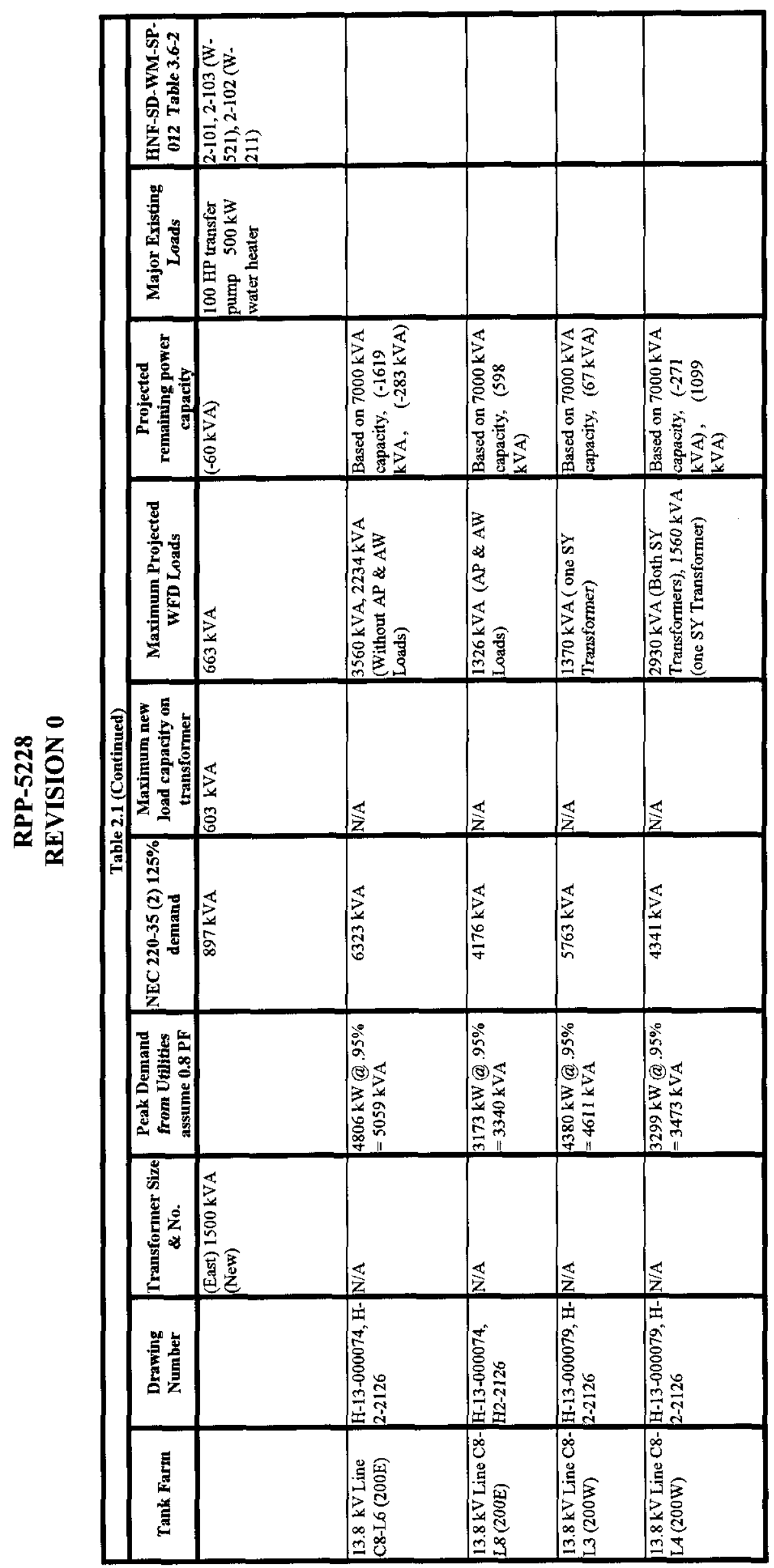




\section{RPP-5228 \\ REVISION 0}

The existing transformers for AY, AW, and SY Tank Farms do not have sufficient capacity for the added mixer pump/transfer pump and caustic and diluent loads. A new $1000 \mathrm{kVA}$ transformer should be installed to replace the existing $500 \mathrm{kVA}$ transformer at the AW Tank Farm. A new $1000 \mathrm{kVA}$ transformer will also be needed for the AY Tank Farm. The existing AY Tank Farm loads on MCC-AY-1 should be transferred to the new $1000 \mathrm{kVA}$ transformer. The existing loads on the pole-mounted transformers for the 250-hp. booster pump and the 40 -hp. floating pump installed by Project W-320, "Tank 241-C-106 Sluicing" would remain on the pole-mounted transformers.

The two existing $500 \mathrm{kVA}$ transformers for the SY Tank Farm are already too small for the existing, and both transformers should be increased to 1,500 kVA to handle the heater loads and the new mixer pump and transfer pump loads. The transformers would also provide power to support the future SST retrieval of waste from the S and SX Tank Farms. The power for the SST retrieval would require the addition of a $40-\mathrm{hp}$. floating pump and a 250 -hp. booster pump load in tanks SY-101 and SY-103.

The capacity of the existing $13.8 \mathrm{kV}$ line C8-L6 (7 mvA) which feeds the 200 East Tank Farms will be overloaded if the maximum number of ten mixer pumps and five transfer pumps are running at the same time. Tank Farms AW and AP transformer loads should be moved to the $13.8 \mathrm{kV}$ line C8-L8 which was used to feed PUREX to reduce the load on the C8-L6 line. Line C8-L8 exists just west of the AW Tank Farm, and with the installation of sectional switches and the addition of a small section of pole line, the AW and AP transformers could be changed over to the $13.8 \mathrm{kV}$ line C8-L8.

\section{Assessment Item \#3 - Assess the electrical power required to support the retrieval of waste from a SST.}

The assumption for SST retrievals is that the maximum number of simultaneous retrievals will be one for the Southeast Quadrant (A, AX, and C Tank Farms), and three for the Southwest Quadrant (S, SX, and U), Northwest Quadrant (T, TX, and TY), and Northeast Quadrant (B, BX, and BY). The maximum number of simultaneous retrievals per tank farm is one tank, with the exception of TY Tank Farm that will switch to two simultaneous retrievals after the TX Tank Farm has been retrieved (LMHC 1999).

Project W-320 for tank C-106 was used as a guide, and it was assumed that a $250-\mathrm{hp}$. slurry pump, 40-hp. floating pump, and $30 \mathrm{~kW}$ HVAC loads would be required for retrieval in each SST farm. A new pad-mounted 225-kVA transformer should be installed at each SST farm except for the A and AX Tank Farms where the power could come from the existing A Tank Farm 1,000 kVA transformer. The recirculation requirements for tank AY-102 already exist and are included in Assessment Item \# 1. The recirculation pumping for tanks SY101 and SY-103 was included in the requirements for the SY Tank Farm in Assessment Item \# 2 . 


\section{RPP-5228 \\ REVISION 0}

The recirculation pumping, a transfer pump, and a floating pump would come from three new Waste Retrieval Facilities (WRF) for transfers back to the SST farms for the B, BX, BY Tank Farms, T, TX, TY Tank Farms and U Tank Farm. The pumping of waste from the WRFs to the receiving tanks SY-102 and AY-102, and in the AN Tank Farm would be included in the WRF electrical power loads. Electrical power was not included in this study for the WRFs, as it will be installed by a future project.

The existing transformer loads that now power the SST farms storage and saltwell pumping electrical loads should remain as installed until the SST farms have been fully retrieved.

Table 2.2 provides the summary data associated with each SST farm except for retrieval loads. The data was compiled in Letter Report Assessment of the SST Safe Storage Electrical Power Requirements (ARES 99RL0225, 1999).

Table 2.2. Single-Shell Tank Farms Power Requirements

\begin{tabular}{|l|l|c|c|c|c|c|}
\hline & & \multicolumn{3}{|c|}{ Trade Study } & \multicolumn{2}{c|}{ Updated Information } \\
\hline Tank Farm & Transformer size & Storage & $\begin{array}{c}\text { Saltwell } \\
\text { Pumping }\end{array}$ & $\begin{array}{c}\text { Total without } \\
\text { characterization }\end{array}$ & $\begin{array}{c}\text { 1995 Metered } \\
\text { Load }\end{array}$ & $\begin{array}{c}\text { 1999 Load } \\
\text { Estimate }\end{array}$ \\
\hline $241-\mathrm{A}$ & $1000 \mathrm{kva}$ & $633.7 \mathrm{kva}$ & $91.7 \mathrm{kva}$ & $725.4 \mathrm{kva}$ & $279.4 \mathrm{kva}$ & $174.7 \mathrm{kva}$ \\
\hline $241-\mathrm{AX}$ & Fed from A & $125.9 \mathrm{kva}$ & $91.7 \mathrm{kva}$ & $217.6 \mathrm{kva}$ & Unavailable & $110 \mathrm{kva}$ \\
\hline $241-\mathrm{B}$ & $112.5 \mathrm{kva}$ & $70.7 \mathrm{kva}$ & $7.2 \mathrm{kva}$ & $77.9 \mathrm{kva}$ & Unavailable & $84.1 \mathrm{kva}$ \\
\hline $241-\mathrm{BX}$ & $30 \mathrm{kva} \& 75 \mathrm{kva}$ & $260.8 \mathrm{kva}$ & $95.5 \mathrm{kva}$ & $356.3 \mathrm{kva}$ & Unavailable & $49.8 \mathrm{kva}$ \\
\hline $241-\mathrm{BY}$ & $1000 \mathrm{kva}$ & $413.1 \mathrm{kva}$ & $87.6 \mathrm{kva}$ & $500.7 \mathrm{kva}$ & Unavailable & $497.4 \mathrm{kva}$ \\
\hline $241-\mathrm{C}$ & $450 \mathrm{kva}$ & $128.5 \mathrm{kva}$ & $13.7 \mathrm{kva}$ & $142.2 \mathrm{kva}$ & $141.8 \mathrm{kva}$ & $341 \mathrm{kva}$ \\
\hline $241-\mathrm{S}$ & $300 \mathrm{kva}$ & $88 \mathrm{kva}$ & $85.1 \mathrm{kva}$ & $173.1 \mathrm{kva}$ & Unavailable & $235 \mathrm{kva}$ \\
\hline $241-\mathrm{SX}$ & $300 \mathrm{kva} \& 75 \mathrm{kva}$ & $248.3 \mathrm{kva}$ & $89.6 \mathrm{kva}$ & $337.9 \mathrm{kva}$ & Unavailable & $222.5 \mathrm{kva}$ \\
\hline $241-\mathrm{T}$ & $100 \mathrm{kva}$ & $53.4 \mathrm{kva}$ & $7.1 \mathrm{kva}$ & $60.5 \mathrm{kva}$ & Unavailable & $60.5 \mathrm{kva}$ \\
\hline $241-\mathrm{TX}$ & $500 \mathrm{kva}$ & $252.4 \mathrm{kva}$ & $165.3 \mathrm{kva}$ & $417.7 \mathrm{kva}$ & Unavailable & $32.5 \mathrm{kva}$ \\
\hline $241-\mathrm{TY}$ & $150 \mathrm{kva}$ & $138.3 \mathrm{kva}$ & $27.1 \mathrm{kva}$ & $165.4 \mathrm{kva}$ & $13.8 \mathrm{kva}$ & $79 \mathrm{kva}$ \\
\hline $241-\mathrm{U}$ & $300 \mathrm{kva}$ & $172.5 \mathrm{kva}$ & $13.6 \mathrm{kva}$ & $186.1 \mathrm{kva}$ & Unavailable & $193 \mathrm{kva}$ \\
\hline
\end{tabular}

- Assessment Item \#4 - Assess the capability of the electrical system to satisfy the electrical power requirements for continued safe storage of waste in both the DSTs and SSTs in the 200 East Area concurrent with DST waste retrieval per activity 2 and retrieval from one SST from A, AX, or C Tank Farms.

The existing transformer for the AN Tank Farm has the capacity to handle the additional electrical load of two 300-hp. mixer pumps and one 60-hp. transfer pump. The present Project W-211 design for the AN-105 mixer pumps shows the mixer pumps fed from the AZ transformer. Document HNF-SD-WM-WP-012, Revision 1, Tank Waste Remediation System Operation and Utilization Plan (LMHC 1999) also provides for a new feed from the WRF facility for the B, BX, and BY SST Farm retrieval. No new loads were projected for transfer from the 


\section{RPP-5228 \\ REVISION 0}

WRF to the AN Tank Farm as the transfer pump would be located in the WRF facility.

The existing transformer for the AP Tank Farm has sufficient capacity to handle the additional electrical load of two 300-hp. mixer pumps and one 60-hp. transfer pump. It was assumed that the transfer pumps for the low activity waste feed to the vitrification plant from AP-104 or AP-108 were included as one of the 60 -hp. transfer pumps per farm. The $13.8 \mathrm{kV}$ feeder line should be changed to line C8-L8.

The existing $500 \mathrm{kVA}$ transformer for the AW Tank Farm does not have sufficient capacity to handle the additional electrical load of two 300 -hp. mixer pumps, one 60-hp. transfer pump and the caustic and diluent system. A new transformer (1000 kVA) should be installed for the additional loads plus the existing loads on Motor Control Center (MCC) (EDS-MCC-001) fed from the existing $500 \mathrm{kVA}$ transformer, putting all the AW Tank Farm loads on one transformer. The $13.8 \mathrm{kV}$ feeder line should be changed to line C8-L8 to reduce the load on the line C8-L6.

The existing transformer for the AZ Tank Farm has sufficient capacity to handle the additional electrical load of two 300-hp. mixer pumps and one 60-hp. transfer pump. The $\mathrm{AZ}$ transformer does not have the capacity to handle the additional two 300-hp. mixer pumps and one 60-hp. transfer pump for the AN Tank Farm as presently designed by Project $W-211$. The existing $1000 \mathrm{kVA} \mathrm{AZ}$ Tank Farm transformer will need to be increased to a $2000 \mathrm{kVA}$ transformer if the AN Tank Farm mixer pumps and transfer pump remain on the AZ Tank Farm transformer. The Project W-030, "Tank Farm Ventilation Upgrade," 300 kVA transformer for the AZ/AY Tank Farms should remain as installed for the ventilation system. It was assumed that the transfer pumps for the high-level waste feed to the vitrification plant from tanks AZ-101 or AZ-102 were included as one of the 60-hp. transfer pumps per farm.

The existing transformer which is shared by the A, AX, and AY Tank Farms does not have sufficient capacity to handle the additional electrical load of two 300-hp. mixer pumps and one 60-hp. transfer pump in the AY Tank Farm and the projected loads for the SST retrieval from the A and AX Tank Farms (one 250-hp. booster pump and one 40-hp. float pump). A new transformer (1,000 kVA) should be installed for the new mixer pump and transfer pump loads. The existing loads for SST retrieval (one 250-hp. booster pump and one 40-hp. float pump) should remain on the three pole-mounted transformers installed by Project W-320. The AY Tank Farm loads on MCC-AY-1 (EDS-MCC-601) should be relocated from the A Tank Farm transformer. This arrangement will consolidate the AY Tank Farm loads on the new AY Tank Farm transformer, except for the Project W-030 HVAC loads which are shared with the AZ Tank Farm.

- $\quad$ Assessment Item \#5 - Assess the capability of the electrical system to satisfy the electrical power requirements for continued safe storage of waste in both 


\section{RPP-5228 \\ REVISION 0}

\section{the DSTs and SSTs in the 200 West Area concurrent with DST waste retrieval per activity 2 and retrieval from one SST from S, SX, or U Tank Farm.}

The existing transformers for the SY Tank Farm presently do not have sufficient capacity to handle the existing loads of two $500 \mathrm{~kW}$ heaters and a 100-hp. transfer pump for waste transfer from tanks SY-101 to SY-102. A bank of temporary pole-mounted transformers is being installed to refeed one of the $500 \mathrm{~kW}$ heaters. The additional electrical load to be added consists of two 300-hp. mixer pumps, one 60-hp. transfer pump, and the projected loads for the SST retrieval from the S and SX Tank Farms into the SY-101 and SY-103 tanks (two 250-hp. booster pumps and two $40 \mathrm{hp}$. float pumps). The two existing $500 \mathrm{kVA}$ pad-mounted transformers for the 252-S switchgear SWG-E-001 should be replaced with 1,500 kVA transformers. No new loads were projected for transfer from the U Tank Farm WRF to tank SY-102, as the transfer pump would be located in the WRF facility.

\subsection{CONCLUSIONS}

The existing transformers are adequate to supply the loads in each DST farm for safe storage with the potential exception of the SY Tank Farm. The existing loads and the future loads for mixer pumps, transfer pumps, booster pumps and floating transfer pumps can be fed from the existing transformers in the AN, AP and AZ Tank Farms based on current metering data. Detailed load calculations for these farms are necessary to verify this conclusion. New transformers will be required for the AW, AY, and SY Tank Farms to service the new and existing loads. New transformers for the SY Tank Farm should be a priority item as the existing transformers may not be capable of accepting new loads or changes in load cycle.

The existing switchgear capacity and feeder cable sizes from the transformers to the switchgear will have to be assessed and possibly upgraded for the installation of the new mixer pump motor loads. This assessment/upgrade is the responsibility of projects installing new loads. Any major changes to the criteria will require additional study to assess the impact on the transformer loading.

The backup power supplies (diesel generators or Uninterruptible Power Source) were not looked into during this review. The one-line drawings show a diesel generator installed for the AY/AZ ventilation system and a trailer mounted diesel generator installed for the SY Tank Farm "Train A" ventilation system.

In order to evaluate the backup power requirements, the Double-Shell Waste Tank Safety Equipment List will need to be assessed against the present and future requirements to determine the impact.

To provide a limited source of backup power to the 200 East DST Farm transformers, a cross-tie between the $13.8 \mathrm{kV}$ power lines C8-L6 or C8-L8 and the C8-L5 line and the installation of the $13.8 \mathrm{kV}$ C8-L3 line to one of the SY Tank Farm substation transformers should be considered. 


\subsection{RECOMMENDATIONS}

The following recommendations are offered:

- Install a new transformer for the added loads and the existing loads on MCC-AY1 (EDS-MCC-001) in the AY Tank Farm, replace the AW Tank Farm transformer and both SY Tank Farm transformers with larger transformers. The transformers for the SY Tank Farm need to be changed immediately to reduce the current overloading. Reuse of the $500 \mathrm{kVA}$ transformers removed from the SY Tank Farm for the AW Tank Farm should be considered.

- $\quad$ Change the Project W-211 design for the AN Tank Farm power feed for the mixer pumps from the $\mathrm{AZ}$ transformer to the $\mathrm{AN}$ transformer to consolidate the $\mathrm{AN}$ Tank Farm loads to only one transformer. If the AN Tank Farm two 300-hp. mixer pumps and the 60-hp. transfer pump remain on the AZ Tank Farm transformer, the transformer will need to be changed to $2000 \mathrm{kVA}$.

- Change the $13.8 \mathrm{kV}$ feeder for the $\mathrm{AW}$ and AP Tank Farms transformers from the C8-L6 line to the C8-L8 line to improve on the voltage regulation due to the starting of the 300-hp. mixer pumps and to reduce the load on the C8-L6 line. The load capacity of the C8-L6 line needs to be coordinated with the Utility Group and some reconductoring maybe required due to the added DST loads.

- Install a new $13.8 \mathrm{kV}$ line C8-L3 to one of the SY Tank Farm transformers to improve reliability and provide a means of alternate backup power.

- Install $13.8 \mathrm{kV}$ sectionalizing switches to allow the 200 East Tank Farms to be readily switched to an alternate $13.8 \mathrm{kV}$ source line C8-L5 for temporary limited backup power during loss of $13.8 \mathrm{kV}$ power from either the C8-L6 or C8-L 8 lines.

- Perform load flow and short circuit calculations for each Tank Farm to verify that the cable and equipment ratings will support the existing loads and the projected new loads.

- Monitor the loads on the existing $150 \mathrm{kVA}$ transformers installed by Project W320 and install larger transformers if the $250 \mathrm{HP}$ pump is to be operated under higher load. 


\section{RPP-5228 \\ REVISION 0}

\subsection{UNCERTAINTIES}

The assumptions utilized in this review were not in complete agreement with HNF-SDWM-WP-012, Revision 1, Tank Waste Remediation System Operation and Utilization Plan (LMHC 1999) (Case 3). The assumptions were based on the Statement of Work criteria.

The remaining useful life of the existing facilities was not taken into account, although a cursory review identified no major issues. No reliability requirements were considered in this review. It is probable that a high degree of reliability will be obtained through regular maintenance. Each upgrade should, however, identify a reliability goal and implement appropriate design criteria to obtain this goal.

WRFs are planned in support of SST retrieval, but power requirements for them remain uncertain and are not considered in this review except as stated herein.

\subsection{REFERENCES}

ANSI C57.91, Institute of Electrical and Electronics Engineering (IEEE) Guide for Loading Mineral-Oil-Immersed Transformers.

ARES 1999, Letter, Robert L. Fritz (ARES) to Charles E. Grenard (COGEMA), COGEMA Task Order P-99-032-009 - Transmittal of Letter Report - ARES Task No. 9904910, dated February 22, 1999, ARES Corporation, Richland, Washington (see Appendix C for scope of work).

H-2-2126, Sht. 5 and 7, 200 East Area Electrical Utilities Distribution Map.

H-2-46424, Sht. 1, Electrical One Line Diagram. (SY Tank Farm)

H-2-99389, Sht. 5 and 6, Electrical AY Farm One-Line Diagram.

H-2-818693, Sht. 1, Electrical AY Farm One Line Diagram.

H-13-000074, Sht. 5, 6, and 7, 200 West Area Electrical Utilities Distribution Map.

H-13-000079, Sht. 4 and 6, 200 East Area Electrical Utilities Distribution Map.

H-14-030001, Sht. 1-4, Electrical (EDS) One Line Diagram. (AN Tank Farm)

H-14-030002, Sht. 1-3, Electrical (EDS) One Line Diagram. (AW Tank Farm)

H-14-030003, Sht. 1-4, Electrical (EDS) One Line Diagram. (AP Tank Farm)

H-14-030006, Sht. 1-3, Electrical (EDS) One Line Diagram. (AY Tank Farm) 


\section{RPP-5228 \\ REVISION 0}

H-14-030008, Shts. 1-5, Electrical (EDS) One Line Diagram. (A Tank Farm)

H-14-030031, Sht. 1-5, Electrical (EDS) One Line Diagram. (SY Tank Farm)

H-14-100701, Sht. 1, Electrical Tank 241-SY-102 One Line Diagram. (Project W-211)

H-14-102210, Shts. 1-2, Electrical Tank 241-AP Tank Farm One Line Diagram. (Project W-211)

H-14-102493, Shts. 1-2, Electrical Tank 241-AN-105 One Line Diagram. (Project W-211)

LMHC 1999, Tank Waste Remediation System Operation and Utilization Plan, HNF-SD-WMSP-012, Lockheed Martin Hanford Corporation, Richland, Washington.

NEC 1999, (National Electrical Code) NFPA-70-1999. 


\section{RPP-5228}

REVISION 0

\subsection{PERSONNEL CONTACTED}

- Lockheed Martin Hanford Corp.

M. Al-Wazani Electrical Cognizant Engineer

J. Kriskovich HVAC Cognizant Engineer

J. Roberts 200W Electrical Cognizant Engineer

C. Scaief Instrument Cognizant Engineer

J. Wells 200E Electrical Cognizant Engineer

- COGEMA

R. Spang Project W-314 HVAC Engineer

- Fluor Daniel Hanford Northwest, Inc.

R. Amante Project W-211 Electrical Engineer

- DynCorp

J. Uecker Electrical Engineer

M. Hache Electrical Utility Cognizant Engineer 
RPP-5228

REVISION 0

Appendix A

East Area Transformer Locations

A-1 


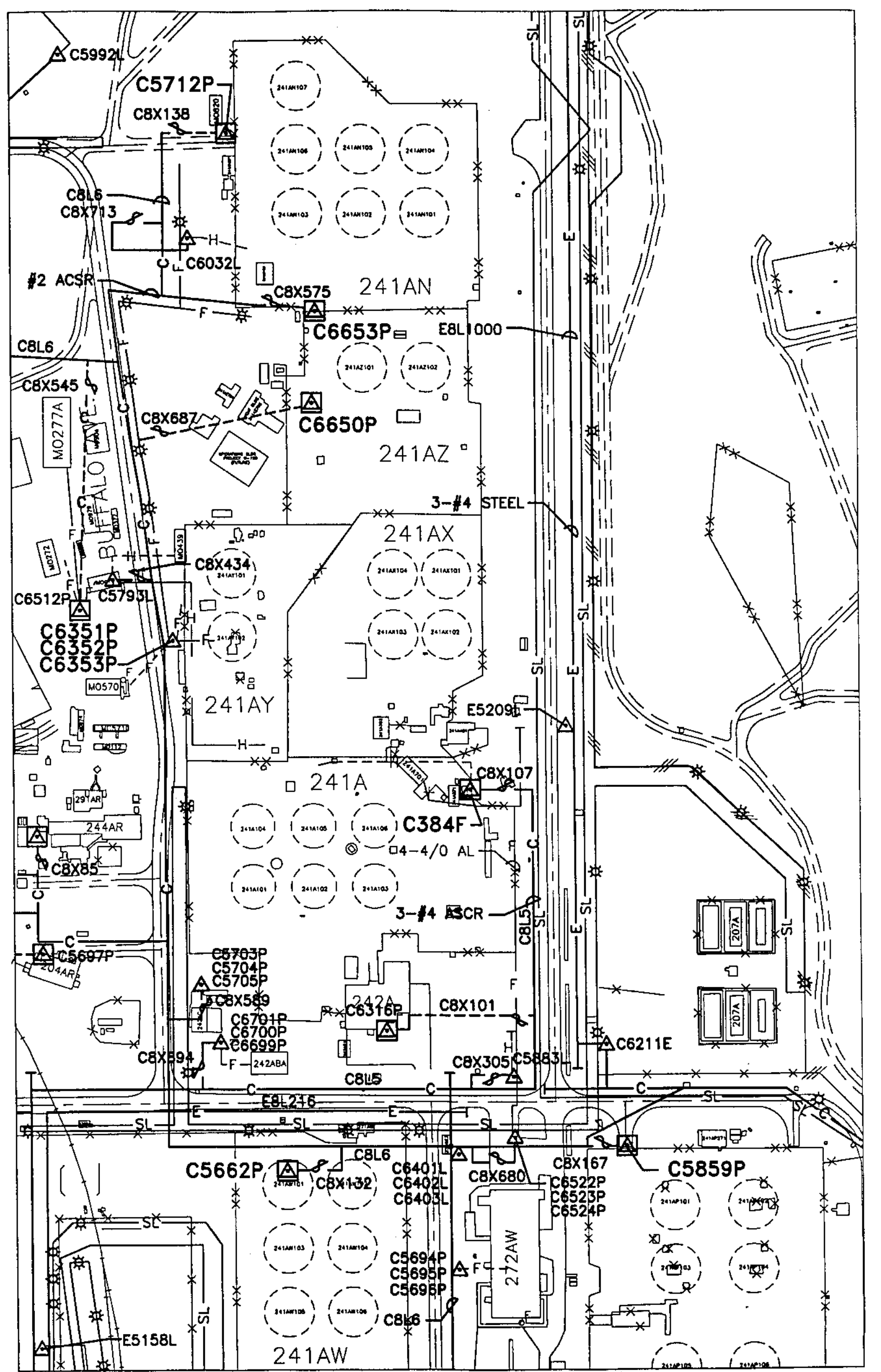


RPP-5228

REVISION 0

Appendix B

Electricity Consumption and Cost Reports

B-1 
ELECTRICITY CONSUMPTION AND COST REPORT

Building

Service (Line, Breaker)

Transformer Number

New Meter Number

Data Logger Number
241-A, 241-AX, 241-AY

CB-LS

C0384F (1,000 KVA)

Meter Difference Old Meter Number NA

084CH72 - 059CH68
Automatic Data

\begin{tabular}{|c|c|c|c|c|c|c|c|c|c|c|}
\hline $\begin{array}{l}\text { Month } \\
\text { \&ear }\end{array}$ & $\begin{array}{l}\text { Percent } \\
\text { Capture }\end{array}$ & $\begin{array}{c}\text { Average } \\
\text { (KW) }\end{array}$ & $\begin{array}{l}\text { Monthly } \\
\text { Consump. } \\
\text { (KWH) }\end{array}$ & $\begin{array}{l}\text { Maximum } \\
\text { (XW) }\end{array}$ & $\begin{array}{l}\text { Minimum } \\
\text { (KW) }\end{array}$ & $\begin{array}{l}\text { Load } \\
\text { Factor }\end{array}$ & $\begin{array}{c}\text { Energy } \\
\text { Cost } \\
\text { (\$) }\end{array}$ & $\begin{array}{c}\text { Demand } \\
\text { Cost } \\
\text { (\$) }\end{array}$ & $\begin{array}{l}\text { Total } \\
\text { Cost } \\
(\$)\end{array}$ & Comments \\
\hline $07 / 97$ & 99.2 & 119.7 & 89,057 & 166.2 & 76.6 & 0.72 & $1,138.15$ & 400.38 & $1,538.52$ & \\
\hline $08 / 97$ & 20.4 & 124.3 & 92,479 & 156.5 & 97.5 & 0.79 & $1,683.12$ & 377.01 & $2,060.13$ & Low \% Capture. \\
\hline $09 / 97$ & 48.3 & 137.9 & 99,288 & 158.2 & 119.5 & 0.87 & $2,165.47$ & 381.10 & $2,546.58$ & Low \% Capture. \\
\hline $10 / 97$ & 100.0 & 143.8 & 106,987 & 171.7 & 115.6 & 0.84 & $2,333.39$ & 413.63 & $2,747.02$ & \\
\hline $11 / 97$ & 99.4 & 159.3 & 114,696 & 200.1 & 107.9 & 0.80 & $2,501.52$ & 482.04 & $2,983.56$ & \\
\hline $12 / 97$ & 100.0 & 189.5 & 140,988 & 255.9 & 131.8 & 0.74 & $3,074.95$ & 616.46 & $3,691.41$ & \\
\hline $01 / 98$ & 98.8 & 205.1 & 152,594 & 252.2 & 138.2 & 0.81 & $3,383.02$ & 607.55 & $3,990.57$ & \\
\hline $02 / 98$ & 99.1 & 177.5 & 119,280 & 234.2 & 127.8 & 0.76 & $2,644.44$ & 564.19 & $3,208.63$ & \\
\hline $03 / 98$ & 98.3 & 138.2 & 102,821 & 221.4 & 53.6 & 0.62 & $2,279.54$ & 533.35 & $2,812.89$ & \\
\hline $04 / 98$ & 97.9 & 69.6 & 50,112 & 136.3 & 29.8 & 0.51 & 993.72 & 328.35 & $1,322.07$ & \\
\hline $05 / 98$ & 92.5 & 69.9 & 52,006 & 125.0 & 42.0 & 0.56 & 540.86 & 301.13 & 841.98 & \\
\hline $06 / 98$ & 92.4 & 57.7 & 41,544 & 125.7 & 28.1 & 0.46 & 432.06 & 302.81 & 734.87 & \\
\hline $07 / 98$ & 99.6 & 52.0 & 38,688 & 76.2 & 23.8 & 0.68 & 494.43 & 183.57 & 678.00 & \\
\hline $08 / 98$ & 99.1 & 70.6 & 52,526 & 171.3 & 29.7 & 0.41 & 955.98 & 412.66 & $1,368.64$ & \\
\hline $09 / 98$ & 98.1 & 63.3 & 45,576 & 87.8 & 41.1 & 0.72 & 994.01 & 211.51 & $1,205.52$ & \\
\hline $10 / 98$ & 98.7 & 73.7 & 54,833 & 109.7 & 41.5 & 0.67 & $1,195.90$ & 264.27 & $1,460.17$ & \\
\hline $11 / 98$ & 92.4 & 82.1 & 59,112 & 125.5 & 39.4 & 0.65 & $1,289.23$ & 302.33 & $1,591.56$ & \\
\hline $12 / 98$ & 97.4 & 121.7 & 90,545 & 179.8 & 52.2 & 0.68 & $1,974.78$ & 433.14 & $2,407.92$ & \\
\hline $01 / 99$ & 99.7 & 114.2 & 84,965 & 151.8 & 79.4 & 0.75 & $1,883.67$ & 365.69 & $2,249.36$ & \\
\hline $02 / 99$ & 99.6 & 103.5 & 69,552 & 137.6 & 63.5 & 0.75 & $1,541.97$ & 331.48 & $1,873.45$ & \\
\hline $03 / 99$ & 98.3 & 95.6 & 71,126 & 135.5 & 57.4 & 0.71 & $1,576.87$ & 326.42 & $1,903.29$ & \\
\hline 04199 & 99.4 & 88.1 & 63,432 & 123.9 & 57.5 & 0.71 & $1,257.86$ & 298.48 & $1,556.33$ & \\
\hline $05 / 99$ & 99.6 & 73.8 & 54,907 & 129.4 & 45.8 & 0.57 & 571.03 & 311.72 & 882.76 & \\
\hline $06 / 99$ & 99.4 & 62.0 & 44,640 & 91.3 & 41.4 & 0.68 & 464.26 & 219.94 & 684.20 & \\
\hline Average & 92.8 & 108.0 & 78,823 & 155.1 & 68.4 & 0.70 & $1,557.09$ & 373.72 & $1,930.81$ & \\
\hline Maximum & 100.0 & 205.1 & 152,594 & 255.9 & 138.2 & 0.87 & $3,383.02$ & 616.46 & $3,990.57$ & \\
\hline
\end{tabular}




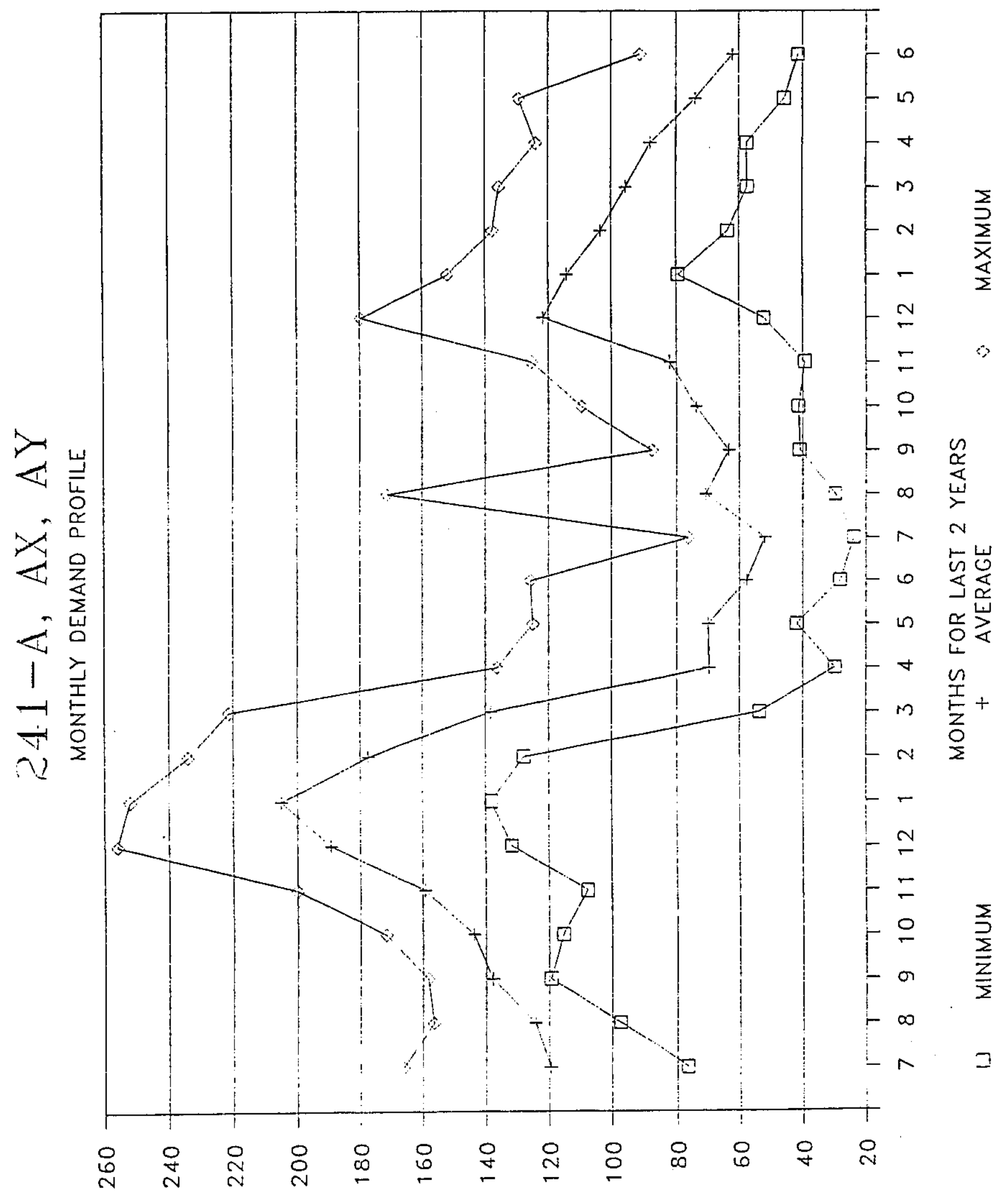


Building

Service (Line, Breaker)

Iransformer Number

New Heter Number

New Multiplier

New Number of Dials
241-AY-051 sluice Pumps

C8-16, $F 8 \times 694$

C6351P, C6352P, C6353P (150 KVA)

$95 \cdot 875 \cdot 449$

5 Old Multiplier

5 Old Number of Dials
Manual Readings
NA

NA

NA

\begin{tabular}{|c|c|c|c|c|c|c|c|c|c|c|c|}
\hline Date & $\begin{array}{l}\text { Energy } \\
\text { Reading }\end{array}$ & $\begin{array}{l}\text { Differ- } \\
\text { ence }\end{array}$ & $\begin{array}{c}\text { Monthly } \\
\text { Consump. } \\
\text { (XWY) }\end{array}$ & $\begin{array}{c}\text { Average } \\
(X W)\end{array}$ & $\begin{array}{l}\text { Demand } \\
\text { Reading }\end{array}$ & $\begin{array}{c}\text { Demand } \\
(K W)\end{array}$ & $\begin{array}{l}\text { Load } \\
\text { Factor }\end{array}$ & $\begin{array}{c}\text { Energy } \\
\text { Cost } \\
(\$)\end{array}$ & $\begin{array}{c}\text { Demand } \\
\text { Cost } \\
\text { (\$) }\end{array}$ & $\begin{array}{l}\text { Total } \\
\text { Cost } \\
(\$)\end{array}$ & Comments \\
\hline $07 / 09 / 97$ & 7303 & & & & & & & & & & \\
\hline $08 / 14 / 97$ & 8099 & 796 & 3,980 & 5 & 1.3 & 7 & 0.71 & 50.86 & 15.66 & 66.52 & Demand Not Reset. \\
\hline $09 / 05 / 97$ & 8567 & 468 & 2,340 & 4 & 1.1 & 6 & 0.81 & 42.59 & 13.25 & 55.84 & \\
\hline $10 / 03 / 97$ & 9153 & 586 & 2,930 & 4 & 1.3 & 7 & 0.67 & 63.90 & 15.66 & 79.56 & \\
\hline $11 / 12 / 97$ & 9981 & 828 & 4,140 & 4 & 1.2 & 6 & 0.72 & 90.29 & 14.45 & 104.75 & \\
\hline $12 / 02 / 97$ & 10380 & 399 & 1,995 & 4 & 1.1 & 6 & 0.76 & 43.51 & 13.25 & 56.76 & \\
\hline $01 / 07 / 98$ & 10867 & 487 & 2,435 & 3 & 1.4 & 7 & 0.40 & 53.11 & 16.86 & 69.97 & \\
\hline $01 / 30 / 98$ & 11190 & 323 & 1,615 & 3 & 1.0 & 5 & 0.59 & 35.80 & 12.05 & 47.85 & \\
\hline $03 / 09 / 98$ & 11516 & 326 & 1,630 & 2 & 0.9 & 5 & 0.40 & 36.14 & 10.84 & 46.98 & \\
\hline $04 / 08 / 98$ & 11676 & 160 & 800 & 1 & 0.8 & 4 & 0.28 & 17.74 & 9.64 & 27.37 & \\
\hline $05 / 05 / 98$ & 11767 & 91 & 455 & 1 & 1.1 & 6 & 0.13 & 9.02 & 13.25 & 22.27 & \\
\hline $06 / 01 / 98$ & 11847 & 80 & 400 & 1 & 0.9 & 5 & 0.14 & 4.16 & 10.84 & 15.00 & \\
\hline $07 / 01 / 98$ & 11963 & 116 & 580 & $i$ & 0.8 & 4 & 0.20 & 6.03 & 9.64 & 15.67 & \\
\hline $08 / 14 / 98$ & 12213 & 250 & 1,250 & 1 & 1.0 & 5 & 0.24 & 15.98 & 12.05 & 28.02 & \\
\hline $09 / 08 / 98$ & 12345 & 132 & 660 & 1 & 0.7 & 4 & 0.31 & 12.01 & 8.43 & 20.44 & \\
\hline $10 / 05 / 98$ & 12435 & 90 & 450 & 1 & 0.7 & 4 & 0.20 & 9.81 & 8.43 & 18.25 & Demand Not Reset. \\
\hline $11 / 10 / 98$ & 12632 & 197 & 985 & 1 & 1.4 & 7 & 0.16 & 21.48 & 16.86 & 38.35 & \\
\hline $12 / 04 / 98$ & 12875 & 243 & 1,215 & 2 & 11.8 & 59 & 0.04 & 26.50 & 142.13 & 168.63 & \\
\hline $01 / 08 / 99$ & 13474 & 599 & 2,995 & 4 & 3.1 & 16 & 0.23 & 65.32 & 37.34 & 102.66 & \\
\hline $02 / 09 / 99$ & 13999 & 525 & 2,625 & 3 & 1.1 & 6 & 0.62 & 58.20 & 13.25 & 71.45 & \\
\hline $03 / 01 / 99$ & 14321 & 322 & 1,610 & 3 & 0.8 & 4 & 0.84 & 35.69 & 9.64 & 45.33 & \\
\hline $04 / 07 / 98$ & 14957 & 636 & 3,180 & 4 & 19.9 & 100 & 0.04 & 70.50 & 239.70 & 310.20 & \\
\hline $05 / 03 / 99$ & 15308 & 351 & 1,755 & 3 & 20.7 & 104 & 0.03 & 34.80 & 249.33 & 284.13 & \\
\hline $06 / 01 / 98$ & 15490 & 182 & 910 & 1 & 18.0 & 90 & 0.01 & 9.46 & $216.81^{\circ}$ & 226.27 & \\
\hline $07 / 06 / 99$ & 15794 & 304 & 1,520 & 2 & 20.8 & 104 & 0.02 & 15.81 & 250.54 & 266.34 & \\
\hline Average & & & 1,769 & 2 & & 24 & 0.10 & 34.53 & 56.66 & 91.19 & \\
\hline Maximum & & & 4,140 & 5 & & 104 & 0.84 & 90.29 & 250.54 & 310.20 & \\
\hline
\end{tabular}




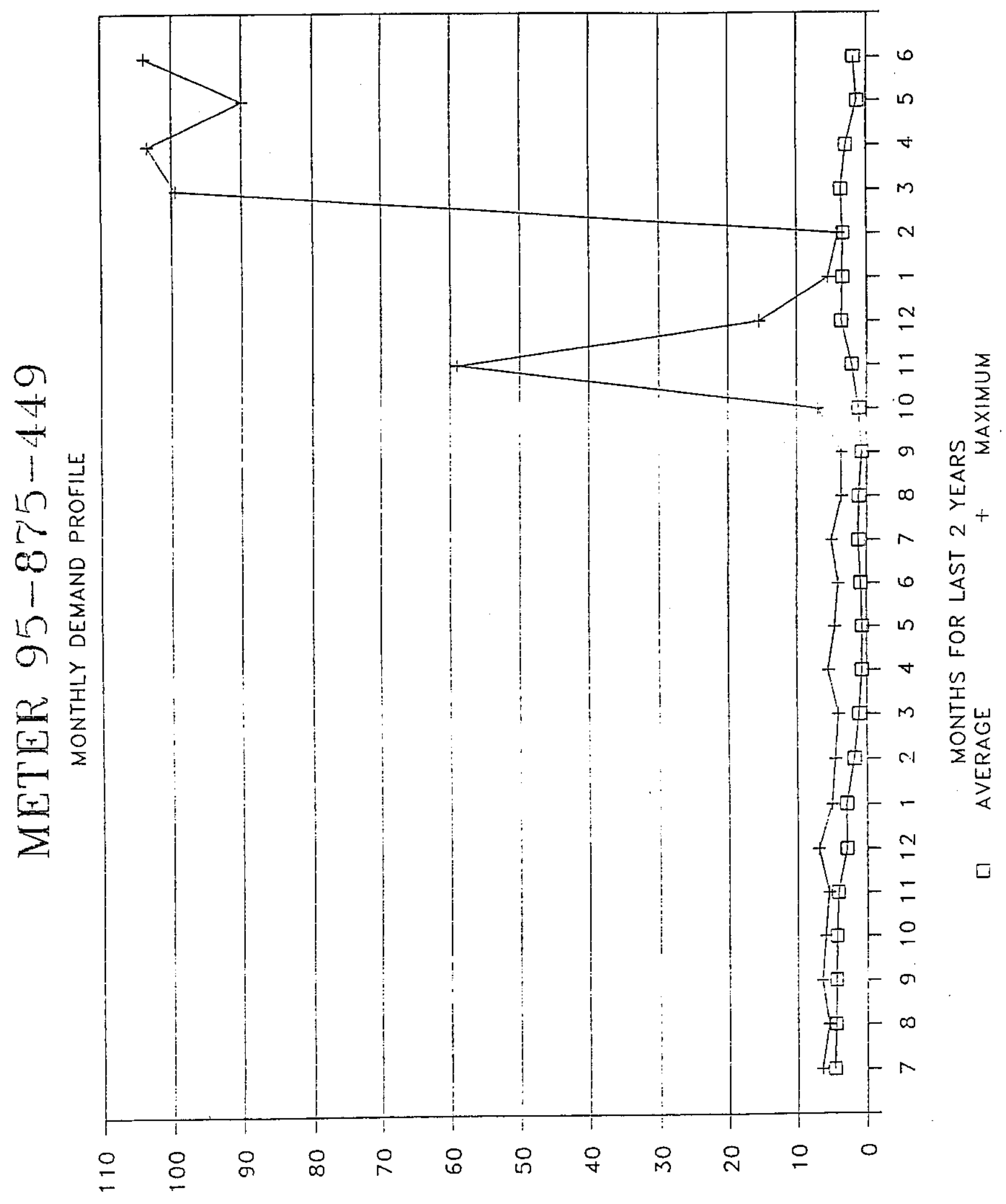


Building

Service (Line, Breaker)

Transformer Number

New Meter Number

New Multiplier

New Number of Dials 241-c-106 sivice Pumps

C8-L6, F8x700

C6646P (225 KVA)

$92-592-538$

40 old Meter Number

old Multiplier

Old Number of Dials
Manual Readings

NA

NA

NA

\begin{tabular}{|c|c|c|c|c|c|c|c|c|c|c|c|}
\hline Date & $\begin{array}{l}\text { Energy } \\
\text { Reading }\end{array}$ & $\begin{array}{l}\text { Differ- } \\
\text { ence }\end{array}$ & $\begin{array}{c}\text { Monthly } \\
\text { Consump. } \\
\text { (KWH) }\end{array}$ & $\begin{array}{c}\text { Average } \\
(K W)\end{array}$ & $\begin{array}{l}\text { Demand } \\
\text { Reading }\end{array}$ & $\begin{array}{l}\text { Demand } \\
(K W)\end{array}$ & $\begin{array}{l}\text { Load } \\
\text { Factor }\end{array}$ & $\begin{array}{c}\text { Energy } \\
\text { cost } \\
\text { (s) }\end{array}$ & $\begin{array}{l}\text { Demand } \\
\text { Cost } \\
\text { (\$) }\end{array}$ & $\begin{array}{l}\text { Total } \\
\text { Cost } \\
(\$)\end{array}$ & Comments \\
\hline $07 / 11 / 97$ & 2953 & & & & & & & & & & \\
\hline $08 / 15 / 97$ & 3013 & 60 & 2,400 & 3 & 0.31 & 12 & 0.23 & 30.67 & 29.87 & 60.54 & \\
\hline $09 / 05 / 97$ & 3113 & 100 & 4,000 & 8 & 0.29 & 12 & 0.68 & 72.80 & 27.94 & 100.74 & \\
\hline $10 / 03 / 97$ & 3344 & 231 & 9,240 & 14 & 0.84 & 34 & 0.41 & 201.52 & 80.94 & 282.47 & \\
\hline $11 / 12 / 97$ & 3669 & 325 & 13,000 & 14 & 0.68 & 27 & 0.50 & 283.53 & 65.52 & 349.05 & \\
\hline $12 / 03 / 97$ & 3889 & 220 & 8,800 & 17 & 0.65 & 26 & 0.67 & 191.93 & 62.63 & 254.56 & \\
\hline $01 / 07 / 98$ & 4320 & 431 & 17,240 & 21 & 0.78 & 31 & 0.66 & 376.00 & 75.16 & 451.17 & \\
\hline $02 / 02 / 98$ & 4608 & 288 & 11,520 & 18 & 0.80 & 32 & 0.58 & 255.40 & 77.09 & 332.49 & \\
\hline $03 / 09 / 98$ & 5156 & 548 & 21,920 & 26 & 1.03 & 41 & 0.63 & 485.97 & 99.25 & 585.22 & \\
\hline $04 / 08 / 98$ & 5636 & 480 & 19,200 & 27 & 1.19 & 48 & 0.56 & 425.66 & 114.67 & 540.33 & \\
\hline $05 / 05 / 98$ & 5796 & 160 & 6,400 & 10 & 0.84 & 34 & 0.29 & 126.91 & 80.94 & 207.85 & \\
\hline $06 / 02 / 98$ & 5903 & 107 & 4,280 & 6 & 0.29 & 12 & 0.55 & 44.51 & 27.94 & 72.46 & \\
\hline $07 / 01 / 98$ & 6101 & 198 & 7,920 & 11 & 1.37 & 55 & 0.21 & 82.37 & 132.01 & 214.38 & \\
\hline $08 / 14 / 98$ & 7099 & 998 & 39,920 & 38 & 1.50 & 60 & 0.63 & 510.18 & 144.54 & 654.72 & \\
\hline $09 / 08 / 98$ & 7620 & 521 & 20,840 & 35 & 1.45 & 58 & 0.60 & 379.29 & 139.72 & 599.01 & \\
\hline $10 / 06 / 98$ & 8139 & 519 & 20,760 & 31 & 1.33 & 53 & 0.58 & 452.78 & $i 28.16$ & 580.93 & \\
\hline $11 / 10 / 98$ & 9306 & 1167 & 46,680 & 56 & 1.89 & 76 & 0.74 & $1,018.09$ & 182.12 & $1,200.21$ & \\
\hline $12 / 07 / 98$ & 9980 & 674 & 26,960 & 42 & 2.91 & 116 & 0.36 & 588.00 & 280.41 & 868.41 & \\
\hline $01 / 08 / 99$ & 729 & 749 & 29,960 & 39 & 2.37 & 95 & 0.41 & 653.43 & 228.37 & 881.80 & \\
\hline $02 / 09 / 99$ & 1352 & 623 & 24,920 & 32 & 1.20 & 48 & 0.68 & 552.48 & 115.63 & 668.11 & \\
\hline $03 / 01 / 99$ & 1786 & 434 & 17,360 & 36 & 1.65 & 66 & 0.55 & 384.87 & 158.99 & 543.87 & \\
\hline $04 / 08 / 99$ & 2687 & 901 & 36,040 & 40 & 3.11 & 124 & 0.32 & 799.01 & 299.68 & $1,098.69$ & \\
\hline $05 / 03 / 89$ & 3395 & 708 & 28,320 & 47 & 2.94 & 118 & 0.40 & 561.59 & 283.30 & 844.88 & \\
\hline $06 / 01 / 99$ & 4012 & 617 & 24,680 & 35 & 3.13 & 125 & 0.28 & 256.67 & 301.61 & 558.28 & \\
\hline $07 / 06 / 99$ & 4448 & 436 & 17,440 & 21 & 3.11 & 124 & 0.17 & 181.38 & 299.68 & 481.06 & \\
\hline Average & & & 19,158 & 26 & & 59 & 0.44 & 371.45 & 143.17 & 514.63 & \\
\hline Maximum & & & 46,680 & 56 & & 125 & 0.74 & $1,018.09$ & 301.61 & $1,200.21$ & \\
\hline
\end{tabular}




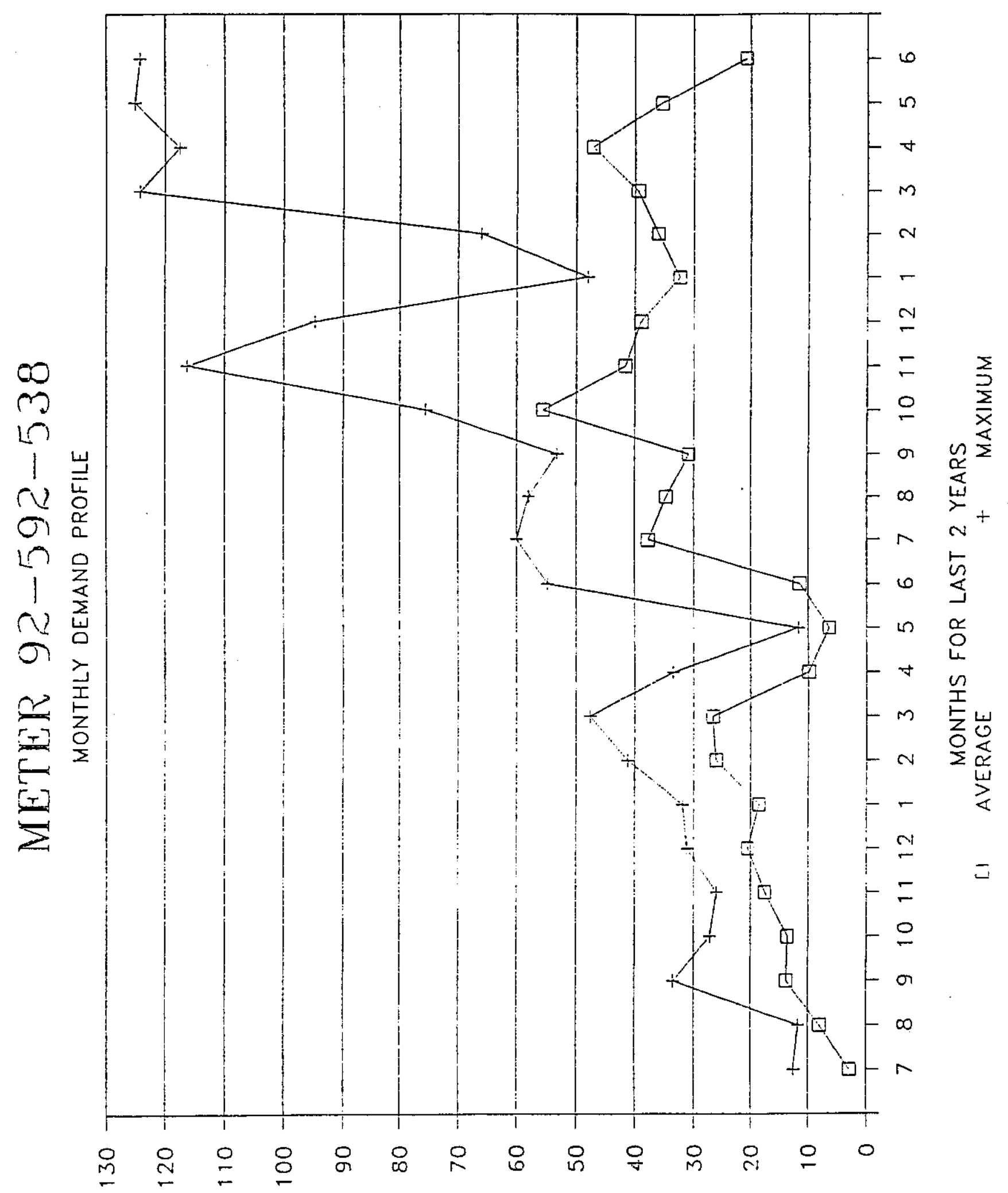


ELECTRICITY CONSUMPTION AND COST REPORT

\begin{abstract}
suilding
Service (Line, Breaker)

Transformer Number
\end{abstract}

New Meter Number

Data Logger Number
241-AZ-156

C8-L6, $F 8 \times 723$

C6653P ( 1,000 KVA)

95-071-095 Old Meter Number

110
Automatic Data

NA

\begin{tabular}{|c|c|c|c|c|c|c|c|c|c|c|}
\hline & & & Monthly & & & & Energy & Demand & Tota! & \\
\hline $\begin{array}{l}\text { Month } \\
\& \text { Year }\end{array}$ & $\begin{array}{l}\text { Percent } \\
\text { Capture }\end{array}$ & $\begin{array}{c}\text { Average } \\
(\mathrm{KW})\end{array}$ & $\begin{array}{l}\text { Consump. } \\
(\text { KWH })\end{array}$ & $\begin{array}{l}\text { Maximum } \\
(\mathrm{KW})\end{array}$ & $\begin{array}{l}\text { Minimum } \\
(\mathrm{KW})\end{array}$ & $\begin{array}{l}\text { Load } \\
\text { factor }\end{array}$ & $\begin{array}{r}\cos t \\
(\$)\end{array}$ & $\begin{array}{r}\cos t \\
(\$)\end{array}$ & $\begin{array}{c}\text { Cost } \\
(\$)\end{array}$ & Conments \\
\hline
\end{tabular}

\begin{tabular}{|c|c|c|c|c|c|c|c|c|c|}
\hline $07 / 97$ & 99.5 & 9.1 & 6,785 & 18.5 & 3.4 & 0.49 & 86.72 & 44.52 & 131.23 \\
\hline $08 / 97$ & 99.7 & 8.4 & 6,250 & 21.8 & 4.6 & 0.38 & 113.74 & 52.61 & 166.36 \\
\hline $09 / 97$ & 99.2 & 7.4 & 5,357 & 12.7 & 4.6 & 0.58 & 116.83 & 30.64 & 147.47 \\
\hline $10 / 97$ & 100.0 & 8.4 & 6,250 & 14.9 & 3.4 & 0.56 & 136.30 & 35.85 & 172.15 \\
\hline $11 / 97$ & 99.9 & 15.1 & 10,886 & 32.2 & 3.4 & 0.47 & 237.43 & 77.47 & 314.91 \\
\hline $12 / 97$ & 99.9 & 17.8 & 13,213 & 32.2 & 8.2 & 0.55. & 288.19 & 77.47 & 365.66 \\
\hline $01 / 98$ & 100.0 & 17.3 & 12,856 & 27.6 & 5.8 & 0.63 & 285.02 & 66.49 & 351.51 \\
\hline $02 / 98$ & 99.0 & 13.4 & 9,032 & 23.0 & 4.6 & 0.58 & 200.23 & 55.50 & 255.74 \\
\hline $03 / 98$ & 99.7 & 11.3 & 8,392 & 19.7 & 3.4 & 0.57 & 186.06 & 47.41 & 233.47 \\
\hline $04 / 98$ & 99.7 & 8.6 & 6,221 & 17.3 & 3.4 & 0.50 & 123.36 & 41.63 & 164.99 \\
\hline $05 / 98$ & 99.9 & 6.7 & 5,000 & 13.9 & 3.4 & 0.48 & 52.00 & 33.53 & 85.53 \\
\hline $06 / 98$ & 99.9 & 6.7 & 4,838 & 12.7 & 3.4 & 0.53 & 50.32 & 30.64 & 80.96 \\
\hline $07 / 98$ & 99.8 & 7.2 & 5,357 & 12.7 & 2.4 & 0.57 & 68.46 & 30.64 & 99.10 \\
\hline $08 / 98$ & 99.9 & 8.6 & 6.428 & 13.9 & 3.4 & 0.62 & 116.99 & 33.53 & 150.53 \\
\hline $09 / 98$ & 99.7 & 8.4 & 6,048 & 14.9 & 3.4 & 0.56 & 131.91 & 35.85 & 167.75 \\
\hline $10 / 98$ & 99.9 & 7.7 & 5,729 & 13.8 & 3.5 & 0.56 & 124.95 & 33.24 & 158.19 \\
\hline $11 / 98$ & 99.9 & 9.4 & 6,768 & 16.1 & 3.5 & 0.58 & 147.61 & 38.78 & 186.39 \\
\hline $12 / 98$ & 99.9 & 12.8 & 9,523 & 23.0 & 4.6 & 0.56 & 207.70 & 55.41 & 263.11 \\
\hline $01 / 99$ & 99.9 & 12.2 & 9,077 & 18.4 & 4.6 & 0.66 & 201.23 & 44.33 & 245.56 \\
\hline $02 / 99$ & 92.9 & 14.1 & 9,475 & 26.5 & 4.6 & 0.53 & 210.07 & 63.84 & 273.90 \\
\hline $03 / 99$ & 99.9 & 16.6 & 12,350 & 31.1 & 5.8 & 0.53 & 273.81 & 74.92 & 348.73 \\
\hline $04 / 99$ & 99.0 & 13.9 & 10,008 & 28.8 & 5.8 & 0.48 & 198.46 & 69.38 & 267.84 \\
\hline $05 / 99$ & 99.1 & 12.7 & 9.449 & 27.6 & 5.8 & 0.46 & 98.27 & 68.49 & 164.76 \\
\hline $06 / 99$ & 99.9 & 12.3 & 8,856 & 23.0 & 5.8 & 0.53 & 92.10 & 55.41 & 147.51 \\
\hline Average & 99.6 & 11.1 & 8,090 & 20.7 & 4.3 & 0.54 & 156.16 & 49.82 & 205.97 \\
\hline Maximum & 100.0 & 17.8 & 13,213 & 32.2 & 8.2 & 0.66 & 288.19 & 77.47 & 365.66 \\
\hline
\end{tabular}




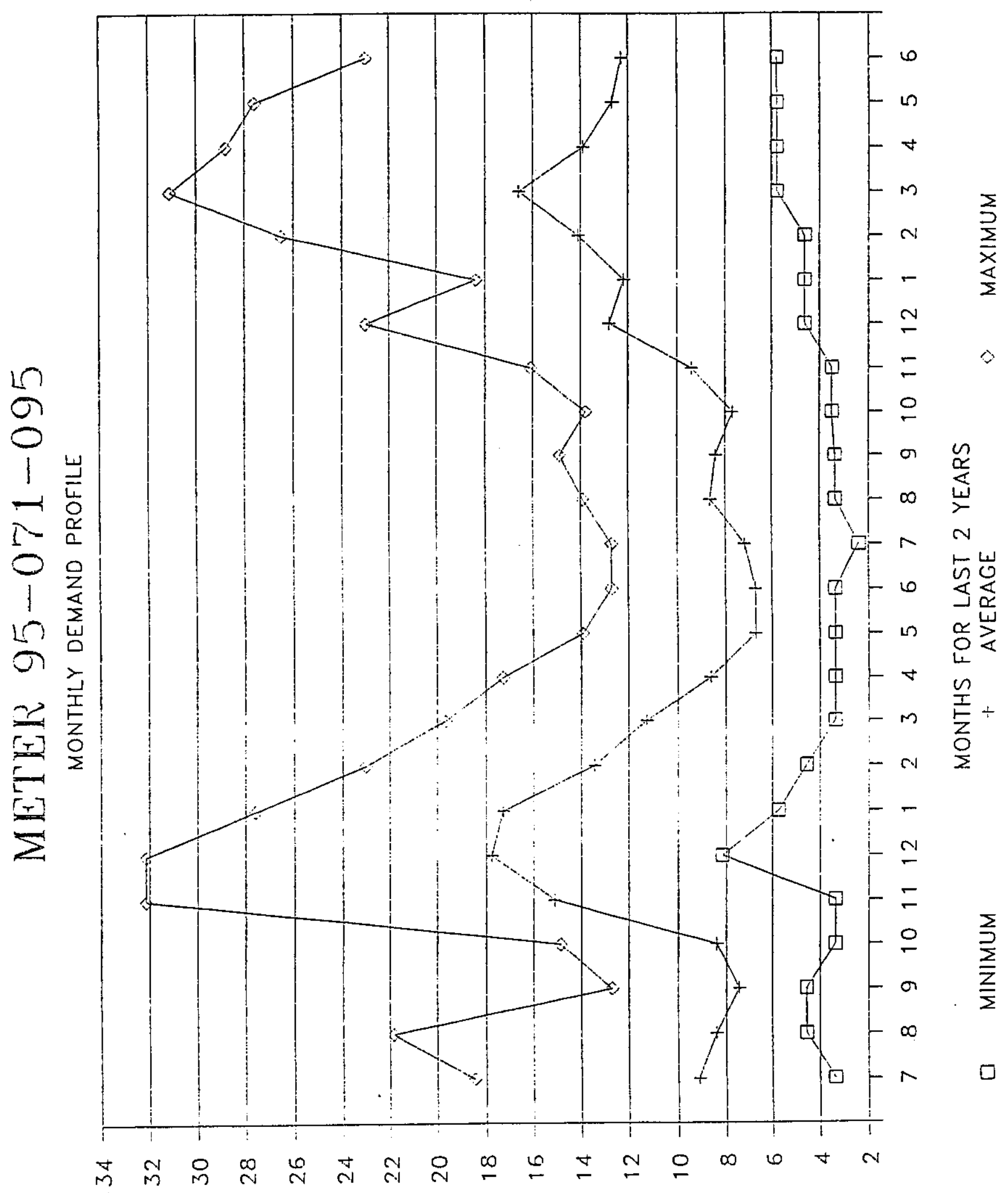


Building

Service (Line, Breaker)

Iransformer Number

New Meter Number

Data Logger Number
241-Az-271, 241-AZ-701, 241-AZ-702 AZ/AY Tank Farm Ventilation system C8-16, $F 8 \times 709$ C665OP (300 KVA)

95-101-149 Old Meter Number NA

116
Automatic Data
Monthly

Month Percent Average Consump.

(XWH)

Q Year Capture (KW)

\section{$07 / 97$}

$08 / 97$

$09 / 97$

$$
10 / 97
$$

$11 / 97$

$12 / 97$

$01 / 98$

$02 / 98$

$03 / 98$

$04 / 98$

$05 / 98$

$06 / 98$

$07 / 98$

$08 / 98$

$09 / 98$

$10 / 98$

$11 / 98$

$12 / 98$

$01 / 99$

$02 / 99$

$03 / 99$

$04 / 99$

$05 / 99$

$06 / 99$

Average

Maximum

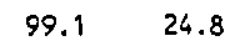

$$
19.1
$$

72.6

1.6

$$
89.3
$$

100.0

$$
99.9
$$

$$
99.9
$$

$$
99.7
$$

$$
93.1
$$

99.1

99.9

99.9

99.3

99.6

99.1

99.9

99.9

99.9

99.7

98.9

99.6

99.9

99.9

24.8

18,451

28.3

29.7

21,055

21,384

40.4

36.2

42.4

32.2

41.6

58.3

59.9

82.9

99.5

121.7

120.7

110.3

104.9

108.1

102.5

112.1

116.4

114.3

113.4

124.2

29,088

26,933

31,546

21,638

30,950

41,976

44,566

59,688

74,028

90,545

86,904

82,063

75,528

80,426

76,260

75,331

86,602

82,296

84,370

89,424

$90.4 \quad 79.3$

$100.0 \quad 124.2$
57,872
90,545

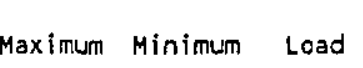

(\$)

Demand

Cost

Total

(5)

(\$) Comments 


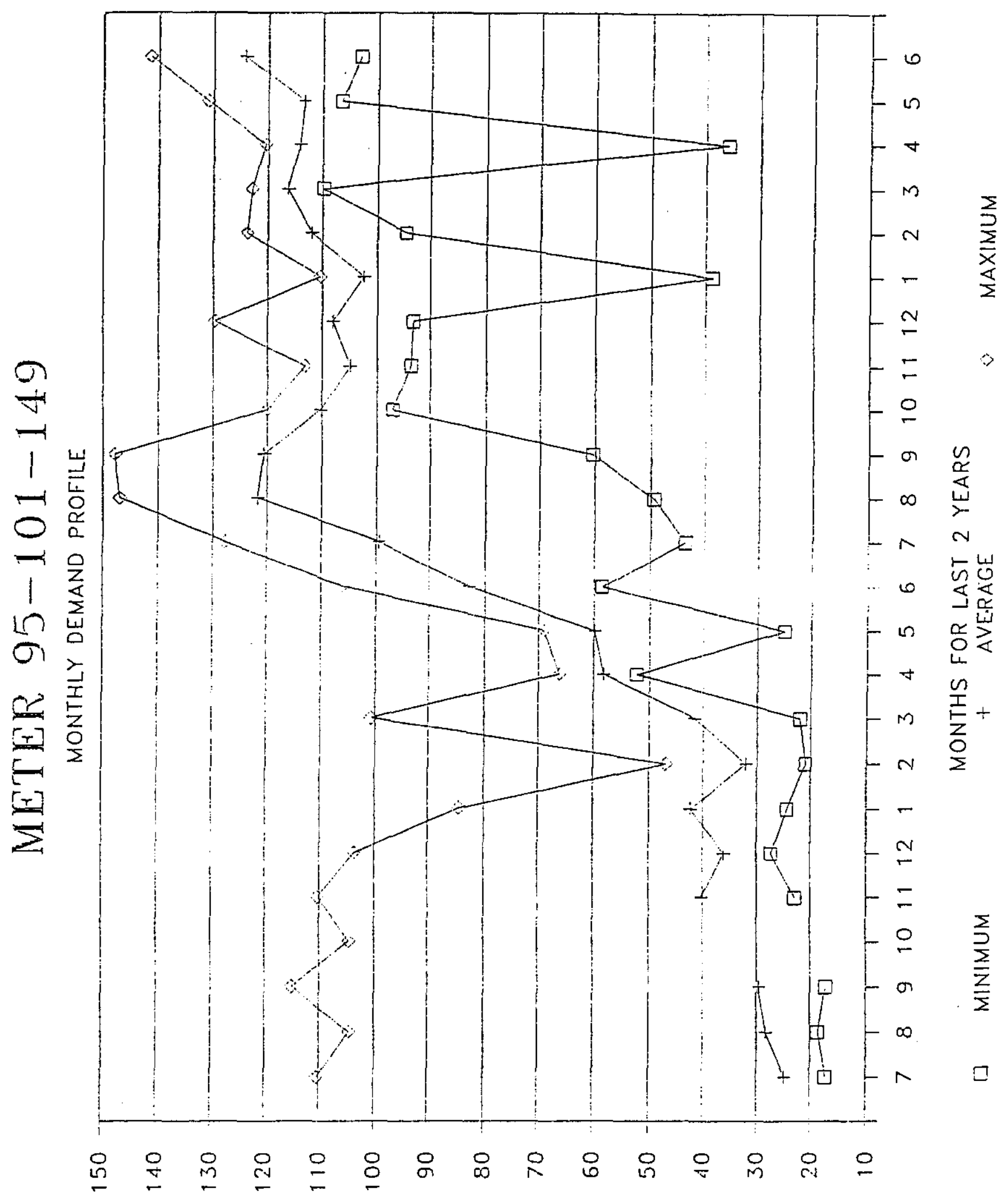




\section{REVISION 0}

ELECTRICITY CONSUMPTION AND COST REPORT

Building
Service (Line,Breaker)
Transformer Number
New Meter Number
Data Logger Number

241-AW Tank farm

C8- 16

C5662P (500 KVA) $30-928-723$ 059
Automatic Data

Old Heter Number NA

\begin{tabular}{|c|c|c|c|c|c|c|c|c|c|c|}
\hline $\begin{array}{l}\text { Month } \\
\& \text { Year }\end{array}$ & $\begin{array}{l}\text { Percent } \\
\text { Capture }\end{array}$ & $\begin{array}{l}\text { Average } \\
\text { (XW) }\end{array}$ & $\begin{array}{c}\text { Monthly } \\
\text { Consump. } \\
\text { (KWH) }\end{array}$ & $\begin{array}{l}\text { Maximum } \\
\text { (KW) }\end{array}$ & $\begin{array}{l}\text { Minimum } \\
(X W)\end{array}$ & $\begin{array}{l}\text { Load } \\
\text { factor }\end{array}$ & $\begin{array}{c}\text { Energy } \\
\text { Cost } \\
\text { (s) }\end{array}$ & $\begin{array}{c}\text { Demand } \\
\text { Cost } \\
\text { (\$) }\end{array}$ & $\begin{array}{l}\text { Total } \\
\text { Cost } \\
(\$)\end{array}$ & Comments \\
\hline $07 / 97$ & 99.3 & 59.7 & 44,417 & 73.6 & 41.6 & 0.81 & 567.65 & 177.30 & 744.95 & \\
\hline $08 / 97$ & 99.9 & 58.5 & 43,524 & 81.6 & 48.0 & 0.72 & 792.14 & 196.57 & 988.71 & \\
\hline $09 / 97$ & 99.9 & 57.7 & 41,544 & 67.2 & 44.8 & 0.86 & 906.07 & 161.88 & $1,067.96$ & \\
\hline $10 / 97$ & 100.0 & 63.4 & 47,170 & 81.6 & 49.6 & 0.78 & $1,028.77$ & 196.57 & $1,225.34$ & \\
\hline $11 / 97$ & 99.7 & 72.7 & 52,344 & 89.6 & 52.8 & 0.81 & $1,141.62$ & 215.85 & $1,357.47$ & \\
\hline$\{2 / 97$ & 100.0 & 73.4 & 54,610 & 94.4 & 43.2 & 0.78 & $1,191.04$ & 227.41 & $1,418.44$ & \\
\hline $01 / 98$ & 99.9 & 70.4 & 52,378 & 97.6 & 43.2 & 0.72 & $1,161.21$ & 235.12 & $1,396.33$ & \\
\hline $02 / 98$ & 99.4 & 66.7 & 44,822 & 91.2 & 43.2 & 0.73 & 993.71 & 219.70 & $1,213.41$ & \\
\hline $03 / 98$ & 98.9 & 58.7 & 43.673 & 86.4 & 41.6 & 0.68 & 968.23 & 208.14 & $1,176.36$ & \\
\hline $04 / 98$ & 99.7 & 52.3 & 37,656 & 70.4 & 41.6 & 0.74 & 746.72 & 169.59 & 916.31 & \\
\hline $05 / 98$ & 93.0 & 49.1 & 36,530 & 70.4 & 40.0 & 0.70 & 379.92 & 169.59 & 549.51 & \\
\hline $06 / 98$ & 92.5 & 53.3 & 38,376 & 73.6 & 38.4 & 0.72 & 399.11 & 177.30 & 576.41 & \\
\hline $07 / 98$ & 99.9 & 60.1 & 44,714 & 75.2 & 40.0 & 0.80 & 571.45 & 181.16 & 752.61 & \\
\hline $08 / 98$ & 99.3 & 51.3 & 38,167 & 65.6 & 38.4 & 0.78 & 694.64 & 158.03 & 852.67 & \\
\hline $09 / 98$ & 98.9 & 52.1 & 37,512 & 67.2 & 27.2 & 0.78 & 818.14 & 161.88 & 980.02 & \\
\hline $10 / 98$ & 99.2 & 61.2 & 45,533 & 80.0 & 40.0 & 0.77 & 993.07 & 192.72 & $1,185.79$ & \\
\hline $11 / 98$ & 93.1 & 66.1 & 47,592 & 84.8 & 43.2 & 0.78 & $1,037.98$ & 204.28 & $1,242.26$ & \\
\hline $12 / 98$ & 98.1 & 68.9 & 51,262 & 104.0 & 44.8 & 0.66 & $1,118.02$ & 250.54 & $1,368.55$ & \\
\hline $01 / 99$ & 99.9 & 62.0 & 46,128 & 86.4 & 40.0 & 0.72 & $1,022.66$ & 208.14 & $1,230.80$ & \\
\hline $02 / 99$ & 100.0 & 67.0 & 45,024 & 84.8 & 46.4 & 0.79 & 998.18 & 204.28 & $1,202.47$ & \\
\hline $03 / 99$ & 99.1 & 66.8 & 49,699 & 88.0 & 43.2 & 0.76 & $9,101.83$ & 211.99 & $1,313.82$ & \\
\hline $04 / 99$ & 99.7 & 61.7 & 44,424 & 84.8 & 46.4 & 0.73 & 880.93 & 204.28 & $1,085.21$ & \\
\hline $05 / 99$ & 99.7 & 59.5 & 44,268 & 84.8 & 46.4 & 0.70 & 460.39 & 204.28 & 664.67 & \\
\hline $06 / 99$ & 99.9 & 58.5 & 42,120 & 81.6 & 44.8 & 0.72 & 438.05 & 196.57 & 634.62 & \\
\hline Average & 98.7 & 61.3 & 44,729 & 81.9 & 42.9 & 0.75 & 850.48 & 197.22 & $1,047.70$ & \\
\hline Maximum & 100.0 & 73.4 & 54,610 & 104.0 & 52.8 & 0.86 & $1,191.04$ & 250.54 & $1,418.44$ & \\
\hline
\end{tabular}




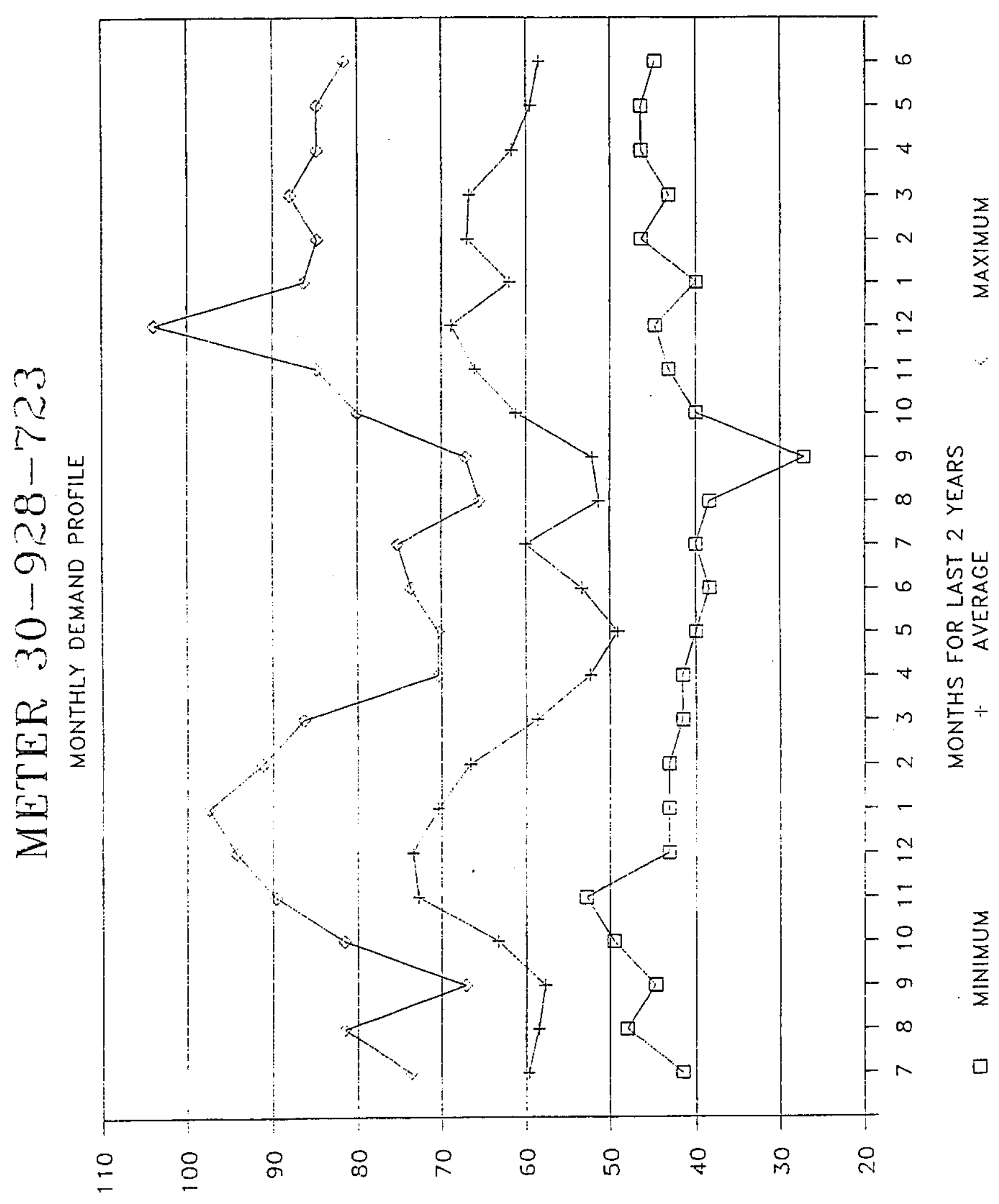


RPP-5228

REVISION 0

ELECTRICITY CONSUMPTION AND COST REPORT

Building
Service (Line, Breaker)
Rransformer Number
New Meter Number
Data Logger Number
241-AN Tank Farm, 271-AN

C8: 16

C5712P ( $1,000 \mathrm{KVA})$

30-935-235 Old Meter Number

067
Automatic Data

NA

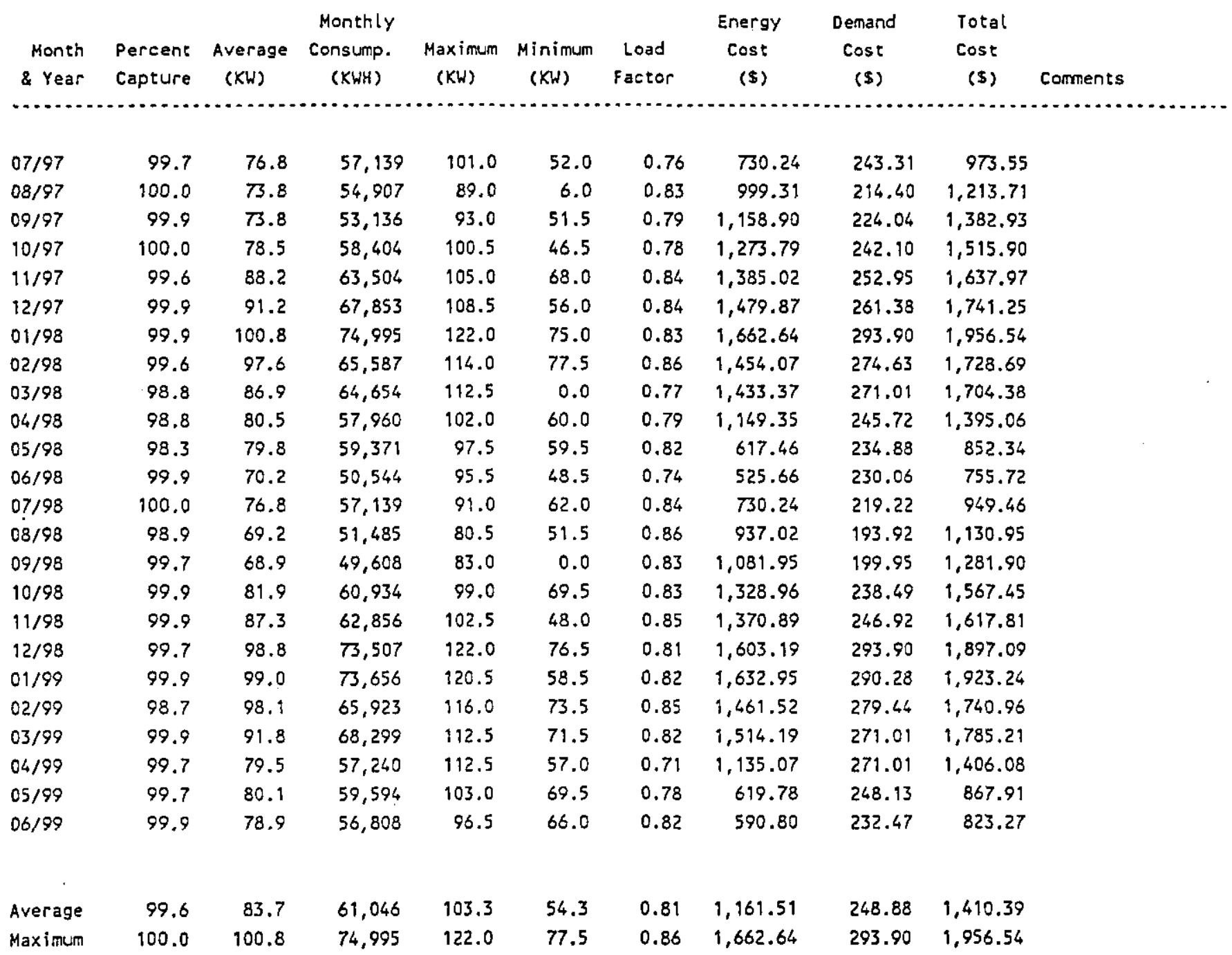




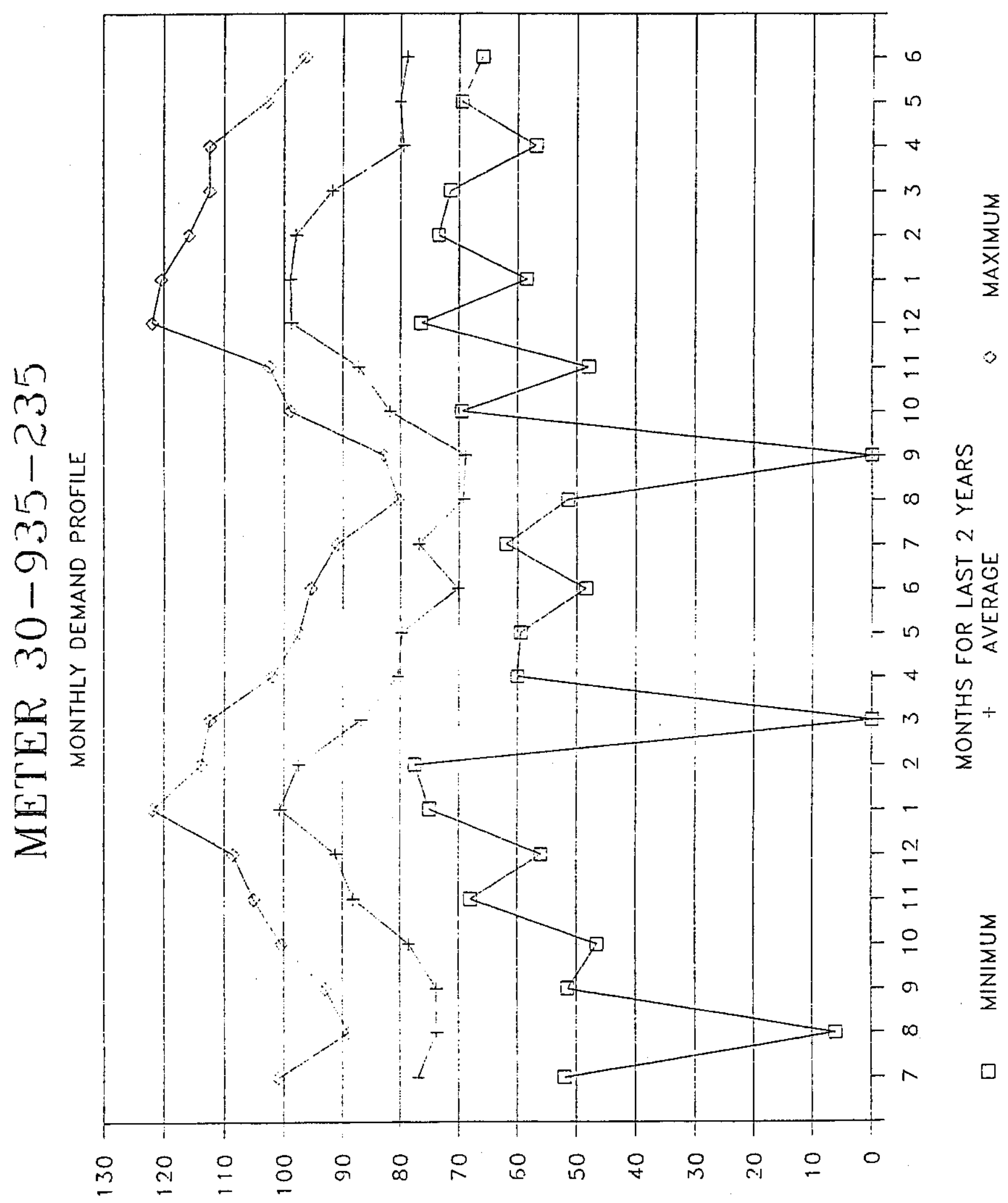




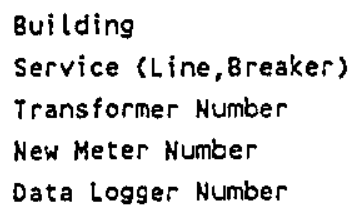

241-AP Tank Farm

$\mathrm{C} 8 . \mathrm{L} 6$ C5859P (1,000 KVA) 69.881 .480 Old Meter Number NA
Automatic Data

\begin{tabular}{|c|c|c|c|c|c|c|c|c|c|c|}
\hline $\begin{array}{l}\text { Month } \\
\& \text { Year }\end{array}$ & $\begin{array}{l}\text { Percent } \\
\text { Capture }\end{array}$ & $\begin{array}{c}\text { Average } \\
(\mathrm{KH})\end{array}$ & $\begin{array}{l}\text { Monthly } \\
\text { Consump. } \\
\text { (KWH) }\end{array}$ & $\begin{array}{l}\text { Maximum } \\
(\mathrm{XW})\end{array}$ & $\begin{array}{l}\text { Minimum } \\
(\mathrm{KW})\end{array}$ & $\begin{array}{l}\text { Load } \\
\text { Factor }\end{array}$ & $\begin{array}{c}\text { Energy } \\
\text { Cost } \\
\text { (\$) }\end{array}$ & $\begin{array}{c}\text { Demand } \\
\text { Cost } \\
(\$)\end{array}$ & $\begin{array}{l}\text { Total } \\
\text { Cost } \\
(\$)\end{array}$ & Comments \\
\hline $07 / 97$ & 99.7 & 73.2 & 54,461 & 94.5 & 59.5 & 0.77 & 696.01 & 227.65 & 923.66 & \\
\hline $08 / 97$ & 100.0 & 72.9 & 54,238 & 91.0 & 38.5 & 0.80 & 987.12 & 219.22 & $1,206.34$ & \\
\hline $09 / 97$ & 99.7 & 78.3 & 56,376 & 92.0 & 66.5 & 0.85 & $1,229.56$ & 221.63 & $1,451.19$ & \\
\hline $10 / 97$ & 100.0 & 87.2 & 64,877 & 121.5 & 64.0 & 0.72 & $1,414.96$ & 292.69 & $1,707.66$ & \\
\hline $11 / 97$ & 99.4 & 101.1 & 72,792 & 126.5 & 30.0 & 0.80 & $1,587.59$ & 304.74 & $1,892.33$ & \\
\hline $12 / 97$ & 98.8 & 108.9 & 81,022 & 153.0 & 0.0 & 0.71 & $1,767.08$ & 368.58 & $2,135.66$ & \\
\hline $01 / 98$ & 99.7 & 107.8 & 80,203 & 140.0 & 0.0 & 0.77 & $1,778.10$ & 337.26 & 2.115 .36 & \\
\hline $02 / 98$ & 99.9 & 101.3 & 68,074 & 122.0 & 79.5 & 0.83 & $1,509.19$ & 293.90 & $1,803.09$ & \\
\hline $03 / 98$ & 99.7 & 94.7 & 70,457 & 118.0 & 74.0 & 0.80 & $1,562.03$ & 284.26 & $1,846.29$ & \\
\hline $04 / 98$ & 99.6 & 95.6 & 68,832 & 118.0 & 77.0 & 0.81 & $1,364.94$ & 284.26 & $1,649.20$ & \\
\hline $05 / 98$ & 99.6 & 89.0 & 66,216 & 106.5 & 70.0 & 0.84 & 688.65 & 256.56 & 945.20 & \\
\hline $06 / 98$ & 100.0 & 82.2 & 59,184 & 95.5 & 63.0 & 0.86 & 615.51 & 230.06 & 845.57 & \\
\hline $07 / 98$ & 99.6 & 78.5 & 58,404 & 93.5 & 60.5 & 0.84 & 746.40 & 225.24 & 971.64 & \\
\hline $08 / 98$ & 99.9 & 78.6 & 58,478 & 93.0 & 61.0 & 0.85 & $1,064.31$ & 224.04 & $1,288.34$ & \\
\hline $09 / 98$ & 98.9 & 80.2 & 57,744 & 98.0 & 61.0 & 0.82 & $1,259.40$ & 236.08 & $1,495.48$ & \\
\hline $10 / 98$ & 99.7 & 90.3 & 67,183 & 113.0 & 70.0 & 0.80 & $1,465.27$ & 272.22 & $1,737.48$ & \\
\hline $11 / 98$ & 100.0 & 98.0 & 70,560 & 119.5 & 79.0 & 0.82 & $1,538.91$ & 287.88 & $1,826.79$ & \\
\hline $12 / 98$ & 99.9 & 113.7 & 84,593 & 150.5 & 88.5 & 0.76 & $1,844.97$ & 362.55 & $2,207,52$ & \\
\hline $01 / 99$ & 99.9 & 117.9 & 87,718 & 167.0 & 93.5 & 0.71 & $1,944.70$ & 402.30 & $2,347.00$ & \\
\hline $02 / 99$ & 98.8 & 113.8 & 76,474 & 138.0 & 94.0 & 0.82 & $1,695.42$ & 332.44 & $2,027.86$ & \\
\hline $03 / 99$ & 93.1 & 126.7 & 94,265 & 156.0 & 93.5 & 0.81 & $2,089.85$ & 375.80 & $2,465.65$ & \\
\hline $04 / 99$ & 99.7 & 127.9 & 92,088 & 164.0 & 103.5 & 0.78 & $1,826.11$ & 395.08 & $2,221.18$ & \\
\hline $05 / 99$ & 98.5 & 119.4 & 88,834 & 156.0 & 102.0 & 0.77 & 923.87 & 375.80 & $1,299.67$ & \\
\hline $06 / 99$ & 99.0 & 110.6 & 79,632 & 137.5 & 91.5 & 0.80 & 828.17 & 331.24 & $1,159.41$ & \\
\hline Average & 99.3 & 97.8 & 71,363 & 123.5 & 67.5 & 0.79 & $1,351.17$ & 297.56 & $1,648.73$ & \\
\hline Maximum & 100.0 & 127.9 & 94,265 & 167.0 & 103.5 & 0.86 & $2,089.85$ & 402.30 & $2,465.65$ & \\
\hline
\end{tabular}




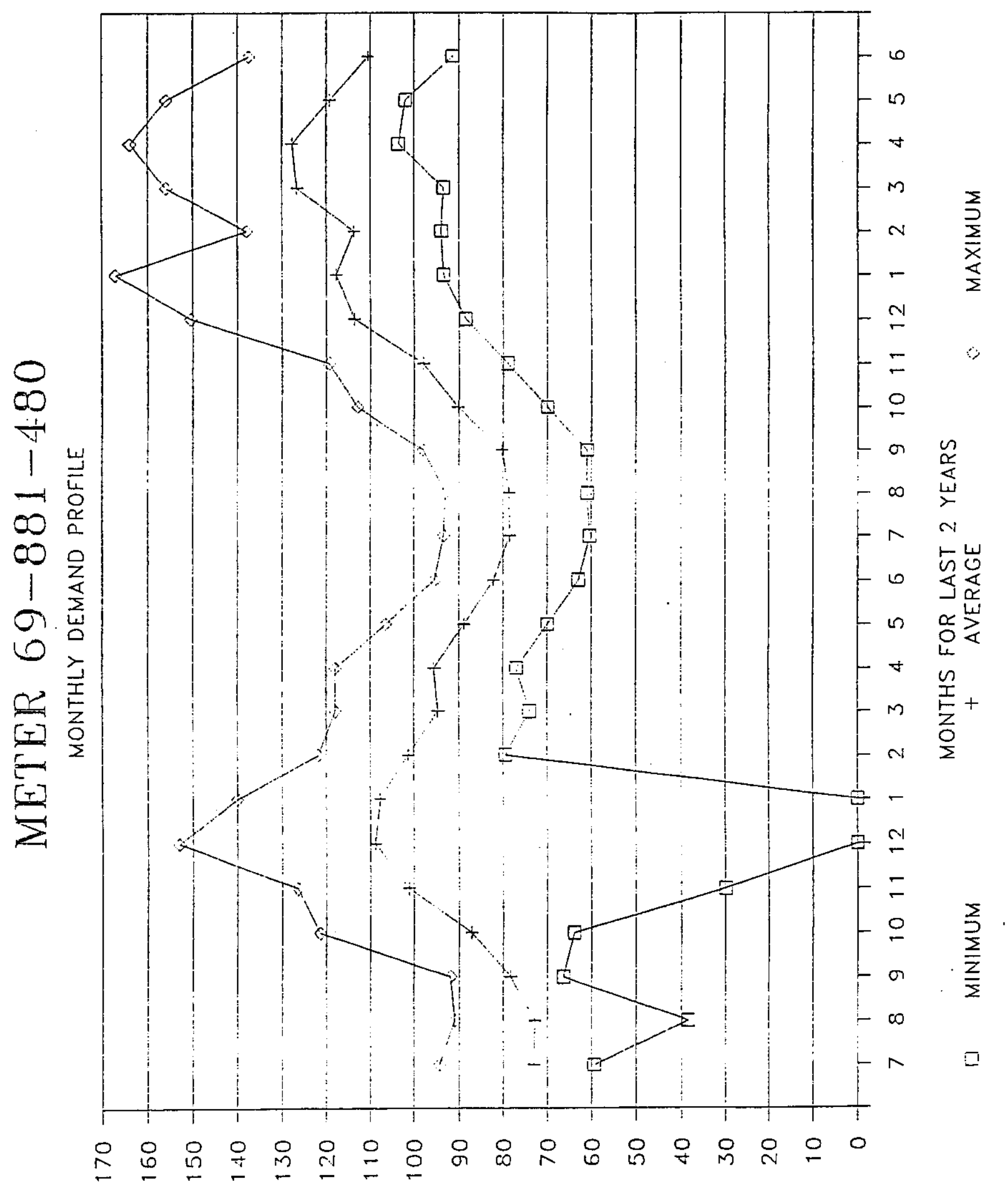


Building

Service (Line, Breaker)

iransformer Number

New Meter Number

Data Logger Number
241-SY Tank Farm, 242-S Evaporator

C8-L4, F8X702

C6647P (500 KVA)

$95 \cdot 031-127$

060
Automatic Data

NA

\begin{tabular}{|c|c|c|c|c|c|c|c|c|c|c|}
\hline $\begin{array}{l}\text { Month } \\
\& \text { Year }\end{array}$ & $\begin{array}{l}\text { Percent } \\
\text { Capture }\end{array}$ & $\begin{array}{c}\text { Average } \\
(\mathrm{KW})\end{array}$ & $\begin{array}{c}\text { Monthly } \\
\text { Consump. } \\
\text { (KWH) }\end{array}$ & $\begin{array}{l}\text { Maximum } \\
(K W)\end{array}$ & $\begin{array}{l}\text { Minimum } \\
(K W)\end{array}$ & $\begin{array}{l}\text { Load } \\
\text { factor }\end{array}$ & $\begin{array}{c}\text { Energy } \\
\text { Cost } \\
\text { (\$) }\end{array}$ & $\begin{array}{c}\text { Demand } \\
\text { Cost } \\
\text { (\$) }\end{array}$ & $\begin{array}{l}\text { Total } \\
\text { Cost } \\
(\$)\end{array}$ & Corments \\
\hline $07 / 97$ & 93.0 & 57.8 & 43,003 & 66.2 & 48.0 & 0.87 & 549.58 & 159.48 & 709.06 & \\
\hline $08 / 97$ & 92.9 & 56.7 & 42,185 & 67.7 & 44.2 & 0.84 & 767.76 & 163.09 & 930.85 & \\
\hline $09 / 97$ & 89.9 & 52.0 & 37,440 & 64.3 & 43.7 & 0.81 & 816.57 & 154.90 & 971.47 & \\
\hline $10 / 97$ & 75.8 & 59.9 & 44,566 & 141.1 & 43.2 & 0.42 & 971.98 & 339.91 & $1,311.89$ & \\
\hline $11 / 97$ & 99.3 & 109.0 & 78,480 & 188.2 & 44.2 & 0.58 & $1,711.65$ & 453.37 & $2,165.02$ & \\
\hline $12 / 97$ & 100.0 & 143.2 & 106,541 & 445.0 & 48.0 & 0.32 & $2,323.65$ & $1,072.00$ & $3,395.66$ & \\
\hline $01 / 98$ & 99.9 & 151.7 & 112,865 & 220.3 & 53.3 & 0.69 & $2,502.21$ & 530.70 & $3,032.92$ & \\
\hline $02 / 98$ & 99.9 & 79.7 & 53,558 & 458.9 & 39.4 & 0.17 & $1,187.39$ & $1,105.49$ & $2,292.88$ & \\
\hline $03 / 98$ & 99.7 & 58.7 & 43,673 & 293.3 & 38.9 & 0.20 & 968.23 & 706.56 & $1,674.79$ & \\
\hline $04 / 98$ & 98.1 & 83.8 & 60,336 & 123.4 & 31.2 & 0.68 & $1,196.46$ & 297.27 & $1,493.73$ & \\
\hline $05 / 98$ & 99.7 & 38.8 & 28,867 & 54.2 & 31.2 & 0.72 & 300.22 & 130.57 & 430.79 & \\
\hline $06 / 98$ & 100.0 & 43.0 & 30,960 & 165.1 & 32.6 & 0.26 & 321.98 & 397.73 & 719.71 & \\
\hline $07 / 98$ & 99.9 & 49.0 & 36,456 & 175.7 & 37.0 & 0.28 & 465.91 & 423.26 & 889.17 & \\
\hline $08 / 98$ & 99.7 & 48.6 & 36,158 & 252.5 & 37.4 & 0.19 & 658.08 & 608.27 & $1,266.36$ & \\
\hline $09 / 98$ & 99.9 & 49.2 & $35,4,24$ & 185.3 & 40.3 & 0.27 & 772.60 & 446.39 & $1,218.99$ & \\
\hline $10 / 98$ & 99.9 & 49.0 & 36,456 & 174.7 & 29.8 & 0.28 & 795.11 & 420.85 & $1,215.96$ & \\
\hline $11 / 98$ & 99.9 & 55.6 & 40,032 & 230.4 & 36.0 & 0.24 & 873.10 & 555.03 & $1,428.13$ & \\
\hline $12 / 98$ & 99.9 & 89.0 & 66,216 & 269.3 & 45.1 & 0.33 & $1,444.17$ & 648.74 & $2,092.91$ & \\
\hline $01 / 99$ & 99.9 & 103.4 & 76,930 & 314.4 & 44.6 & 0.33 & $1,705.53$ & 757.38 & $2,462.92$ & \\
\hline $02 / 99$ & 99.9 & 91.6 & 61,555 & 278.9 & 47.0 & 0.33 & $1,364.68$ & 671.87 & $2,036.55$ & \\
\hline $03 / 99$ & 99.9 & 78.5 & 58,404 & 389.8 & 43.2 & 0.20 & $1,294.82$ & 939.03 & $2,233.84$ & \\
\hline $04 / 99$ & 92.6 & 68.0 & 48,960 & 309.1 & 46.6 & 0.22 & 970.88 & 744.62 & $1,715.50$ & \\
\hline $05 / 99$ & 98.5 & 57.1 & 42,482 & 112.8 & 45.6 & 0.51 & 441.82 & 271.74 & 713.55 & \\
\hline $06 / 99$ & 98.8 & 55.6 & 40,032 & 241.4 & 44.6 & 0.23 & 416.33 & 581.53 & 997.87 & \\
\hline Average & 97.4 & 72.0 & 52,566 & 217.6 & 41.5 & 0.33 & $1,034.20$ & 524.16 & $1,558.35$ & \\
\hline Maximum & 100.0 & 151.7 & 112,865 & 458.9 & 53.3 & 0.87 & $2,502.21$ & $1,105.49$ & $3,395.66$ & \\
\hline
\end{tabular}




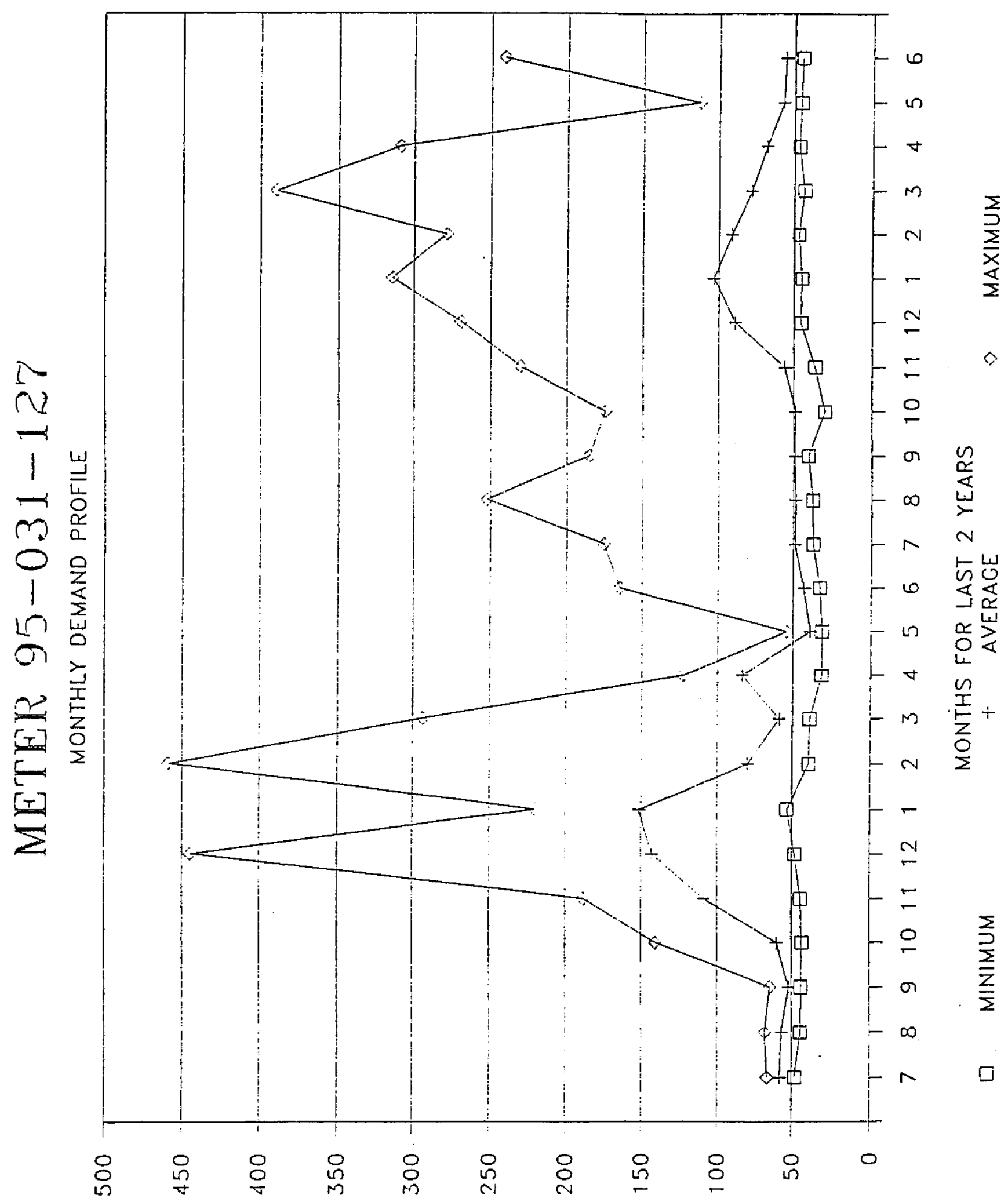




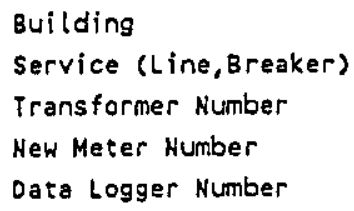

241-SY Tank Farm, 242-S Evaporator

C8-L4, F8X703

(66488 (500 KVA)

95-031-128 Old Meter Number NA
Automatic Data

\begin{tabular}{|c|c|c|c|c|c|c|c|c|c|c|}
\hline $\begin{array}{l}\text { Month } \\
\& \text { Year }\end{array}$ & $\begin{array}{l}\text { Percent } \\
\text { Capture }\end{array}$ & $\begin{array}{c}\text { Average } \\
(X W)\end{array}$ & $\begin{array}{l}\text { Monthly } \\
\text { Consump. } \\
\text { (XWH) }\end{array}$ & $\begin{array}{l}\text { Maximum } \\
(\mathrm{KW})\end{array}$ & $\begin{array}{l}\text { Minimum } \\
\text { (KW) }\end{array}$ & $\begin{array}{l}\text { Load } \\
\text { factor }\end{array}$ & $\begin{array}{c}\text { Energy } \\
\text { Cost } \\
\text { (\$) }\end{array}$ & $\begin{array}{c}\text { Demand } \\
\text { Cost } \\
\text { (\$) }\end{array}$ & $\begin{array}{l}\text { Total } \\
\text { Cost } \\
\text { (\$) }\end{array}$ & Comments \\
\hline & & & & & & . & & & & \\
\hline $07 / 97$ & 93.0 & 50.8 & 37,795 & 119.0 & 28.8 & 0.43 & 483.02 & 286.67 & 769.69 & \\
\hline $08 / 97$ & 92.9 & 48.7 & 36,233 & 119.0 & 24.0 & 0.41 & 659.44 & 286.67 & 946.11 & \\
\hline $09 / 97$ & 89.9 & 45.8 & 32,976 & 109.9 & 22.6 & 0.42 & 719.21 & 264.75 & 983.96 & \\
\hline $10 / 97$ & 75.8 & 50.7 & 37,721 & 114.2 & 23.5 & 0.44 & 822.69 & 275.11 & $1,097.80$ & \\
\hline $11 / 97$ & 99.3 & 58.1 & 41,832 & 116.6 & 25.4 & 0.50 & 912.36 & 280.89 & 1.193 .25 & \\
\hline $12 / 97$ & 100.0 & 67.0 & 49,848 & 436.3 & 26.4 & 0.15 & $1,087.18$ & $1,051.05$ & $2,138.23$ & \\
\hline $01 / 98$ & 99.9 & 63.6 & 47,318 & 256.3 & 26.4 & 0.25 & $1,049.05$ & 617.43 & $1,666,48$ & \\
\hline $02 / 98$ & 99.9 & 56.8 & 38,170 & 183.8 & 23.5 & 0.31 & 846.22 & 442.77 & $1,288.99$ & \\
\hline $03 / 98$ & 99.7 & 48.5 & 36,084 & 109.0 & 24.5 & 0.44 & 799.98 & 262.58 & $1,062.56$ & \\
\hline $04 / 98$ & 98.1 & 44.0 & 31,680 & 107.0 & 25.0 & 0.41 & 628.21 & 257.76 & 885.98 & \\
\hline $05 / 98$ & 99.7 & 37.6 & 27,974 & 101.3 & 22.6 & 0.37 & 290.93 & 244.03 & 534.97 & \\
\hline $06 / 98$ & 100.0 & 41.2 & 29,664 & 243.8 & 23.0 & 0.17 & 308.51 & 587.31 & 895.82 & \\
\hline $07 / 98$ & 99.9 & 45.4 & 33,778 & 262.9 & 24.5 & 0.17 & 431.68 & 631.40 & $1,063.08$ & \\
\hline $08 / 98$ & 99.7 & 45.3 & 33,703 & 244.8 & 22.6 & 0.19 & 613.40 & 589.72 & $1,203.12$ & \\
\hline $09 / 98$ & 99.9 & 44.5 & 32,040 & 240.5 & 22.6 & 0.19 & 698.79 & 579.36 & $1,278.16$ & \\
\hline $10 / 98$ & 99.9 & 43.9 & 32,662 & 312.5 & 21.1 & 0.14 & 712.35 & 752.81 & $1,465.16$ & \\
\hline $11 / 98$ & 99.9 & 44.3 & 31,896 & 291.8 & 21.1 & 0.15 & 695.65 & 702.95 & $1,398.60$ & \\
\hline $12 / 98$ & 99.9 & 57.3 & 42,631 & 478.1 & 24.0 & 0.12 & 929.79 & 1.151 .74 & $2,081.53$ & \\
\hline $01 / 99$ & 99.9 & 62.8 & 46,723 & 436.8 & 24.5 & 0.14 & $1,035.85$ & $1,052.25$ & $2,088.10$ & \\
\hline $02 / 99$ & 99.9 & 64.8 & 43,546 & 333.6 & 25.4 & 0.19 & 965.41 & 803.64 & $1,769.05$ & \\
\hline $03 / 99$ & 99.9 & 62.8 & 46,723 & 540.5 & 24.5 & 0.12 & $1,035.85$ & $1,302.06$ & $2,337.92$ & \\
\hline $04 / 99$ & 92.6 & 54.6 & 39,312 & 574.1 & 25.0 & 0.10 & 779.56 & $1,383.01$ & $2,162.56$ & \\
\hline $05 / 99$ & 98.5 & 57.8 & 43,003 & 525.6 & 3.4 & 0.11 & 447.23 & $1,266.17$ & $1,713,40$ & \\
\hline $06 / 99$ & 98.8 & 53.3 & 38,376 & 554.4 & 24.0 & 0.10 & 399.11 & $1,335.55$ & $1,734.66$ & \\
\hline Average & 97.4 & 52.1 & 37,987 & 283.8 & 23.3 & 0.18 & 722.98 & 683.65 & $1,406.63$ & \\
\hline Maximum & 100.0 & 67.0 & 49,848 & 574.1 & 28.8 & 0.50 & $1,087.18$ & $1,383.01$ & $2,337.92$ & \\
\hline
\end{tabular}




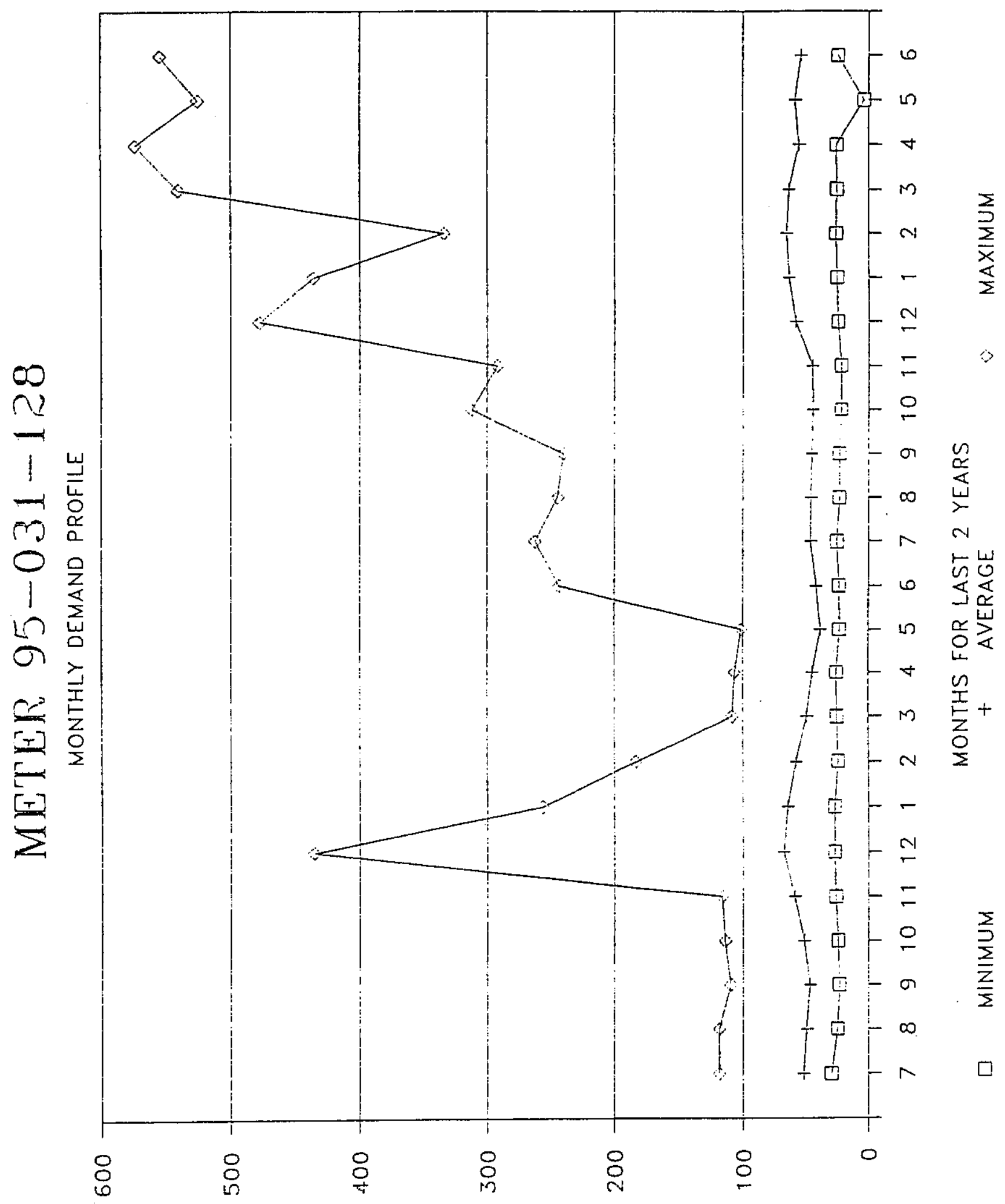


REVISION 0

ELECTRICITY CONSUMPTION ANO COST REPORT

\begin{tabular}{|c|c|c|c|c|c|c|c|c|}
\hline Building & $251 \cdot H$ & & & & & & & \\
\hline Service (Line, Breaker) & $c 8-13, c 8 \times 3$ & & & & & & & Automatic Data \\
\hline Transformer Number & Feeder & & & & & & & \\
\hline New Meter Number & $69-981-182$ & & Old Meter & Number & $\mathrm{k}$ & & & \\
\hline Data Logger Number & 084 & & & & & & & \\
\hline & Monthly & & & & Energy & Demand & Total & \\
\hline Month Percent Average & $\begin{array}{c}\text { Consump. } \\
\text { (KuH) }\end{array}$ & $\begin{array}{l}\text { Maximum } \\
\text { (KW) }\end{array}$ & $\begin{array}{l}\text { Minimum } \\
(K W)\end{array}$ & $\begin{array}{l}\text { Load } \\
\text { Factor }\end{array}$ & $\begin{array}{c}\cos t \\
(\$)\end{array}$ & $\begin{array}{r}\cos t \\
(\$)\end{array}$ & $\begin{array}{c}\cos t \\
(\$)\end{array}$ & coments \\
\hline
\end{tabular}

\begin{tabular}{|c|c|c|c|c|c|c|c|c|c|}
\hline $09 / 97$ & 99.9 & $2,048.1$ & $1,474,632$ & $2,790.0$ & $1,738.0$ & 0.73 & $32,161.72$ & $6,721.11$ & $38,882.83$ \\
\hline $10 / 97$ & 100.0 & $2,115.4$ & $1,573,858$ & $2,842.0$ & $1,388.0$ & 0.74 & $34,325.83$ & $6,846.38$ & $41,172.21$ \\
\hline $11 / 97$ & 99.7 & $2,403.2$ & $1,730,304$ & $3,186.0$ & 1.842 .0 & 0.75 & 37.737 .93 & $7,675.07$ & $45,413.00$ \\
\hline $12 / 97$ & 100.0 & $3,064.5$ & $2,278,988$ & $3,990.0$ & $2,282.0$ & 0.77 & 49.726 .54 & $9,611.91$ & $59,338.45$ \\
\hline $01 / 98$ & 98.9 & $3,182,4$ & $2,367,706$ & $4,380.0$ & $2,293.0$ & 0.73 & $52,492.03$ & $10,551.42$ & $63,043,45$ \\
\hline $02 / 93$ & 99.7 & $2,621.7$ & $1,761,782$ & $3,358.0$ & $2,120.0$ & 0.73 & 39.058 .72 & $8,089,42$ & $47,148.14$ \\
\hline $03 / 98$ & 99.7 & 2.268 .6 & $1,687,838$ & 3.226 .0 & 568.0 & 0.70 & $37,419.38$ & $7,771.43$ & $45,190.81$ Load Transferred. \\
\hline $04 / 98$ & 98.2 & $2,052.1$ & $1,477,512$ & $2,556.0$ & $1,696.0$ & 0.80 & $29,299.05$ & $6,157,40$ & $35,456.47$ \\
\hline $05 / 98$ & 99.5 & $1,795.7$ & $1,336,001$ & $2,384.0$ & $1,136.0$ & 0.75 & $13,894,41$ & $5,743.06$ & $19,637.46$ \\
\hline $06 / 98$ & 99.9 & $1,977.2$ & $1,423,584$ & $2,752.0$ & $1,500.0$ & 0.72 & $14,805.27$ & $6,629.57$ & $21,434.84$ \\
\hline $07 / 98$ & 99.7 & $2,193.3$ & $1,631,815$ & $2,845.0$ & $1,758.0$ & 0.77 & $20,854.60$ & $6,856.01$ & $27,710.61$ \\
\hline $08 / 98$ & 99.7 & $2,128.7$ & $1,583,753$ & $2,826.0$ & $1,612.0$ & 0.73 & $28,824.30$ & $7,048.73$ & $35,873.03$ \\
\hline $09 / 98$ & 99.2 & $2,016.6$ & $1,451,952$ & $2,748.0$ & $1,688.0$ & 0.73 & $31,667.07$ & 6.619 .93 & $38,287.01$ \\
\hline $10 / 98$ & 99.5 & $2,008.2$ & $1,494,101$ & $2,494.0$ & $1,524.0$ & 0.81 & $32,586.34$ & $6,008.05$ & $38,594.38$ \\
\hline $11 / 98$ & 99.3 & $2,220.8$ & $1,596,976$ & $2,674.0$ & $1,430.0$ & 0.83 & 34.873 .67 & $6,441.67$ & $41,315.33$ \\
\hline $12 / 98$ & 99.3 & $2,674.2$ & $1,989,605$ & $3,800.0$ & $2,068.0$ & 0.70 & $43,393.28$ & $9,154.20$ & $52,547.48$ \\
\hline $01 / 97$ & 99.9 & $2,509.4$ & $1,865,994$ & $3,148.0$ & $2,056.0$ & 0.80 & $41,391.25$ & $7,583.53$ & $48,974.78$ \\
\hline $02 / 99$ & 99.7 & $2,386.3$ & $1,603,594$ & $3,052.0$ & $1,540.0$ & 0.78 & $35,551.67$ & $7,352.27$ & $42,903.94$ \\
\hline $03 / 99$ & 99.2 & $2,190.3$ & $1,629,583$ & $2,744.0$ & $1,304.0$ & 0.80 & $36,127.86$ & $6,610.30$ & $42,738.16$ \\
\hline $04 / 99$ & 99.7 & $2,041.2$ & $1,459,664$ & $2,458.0$ & $1,4 \geq 0.0$ & 0.83 & $29,143.44$ & $5,921.32$ & $35,064.76$ \\
\hline $05 / 99$ & 99.9 & 1.973 .6 & $1,468,358$ & $2,632.0$ & $1,422.0$ & 0.75 & $15,270.93$ & $6,340.49$ & $21,611.42$ \\
\hline $06 / 79$ & 99.6 & $1,882.1$ & $1,355,112$ & $3,695.0$ & $1,966.0$ & 0.51 & $14,093,16$ & $8,903.66$ & $22,995.83$ Load Combined. \\
\hline $07 / 99$ & 99.9 & $1,898.9$ & $1,492,782$ & $2,562.0$ & $1,410.0$ & 0.74 & $18,055.35$ & 6.171 .86 & 24.227 .21 \\
\hline $08 / 99$ & 94.5 & 1.952 .7 & $1,452,809$ & $3,795.0$ & 822.0 & 0.51 & $26,441.12$ & $9,144,56$ & $35,585.68$ Load Combined. \\
\hline Average & 99.4 & $2,233.6$ & $1,630,096$ & $3,043.3$ & $9,575.3$ & 0.73 & $31,216.46$ & $7,331.39$ & $38,547.85$ \\
\hline Maximum & 100.0 & $3,182.4$ & $2,367,706$ & $4,380.0$ & $2,298.0$ & 0.83 & $52,492.03$ & $10,551.42$ & $63,043.45$ \\
\hline
\end{tabular}




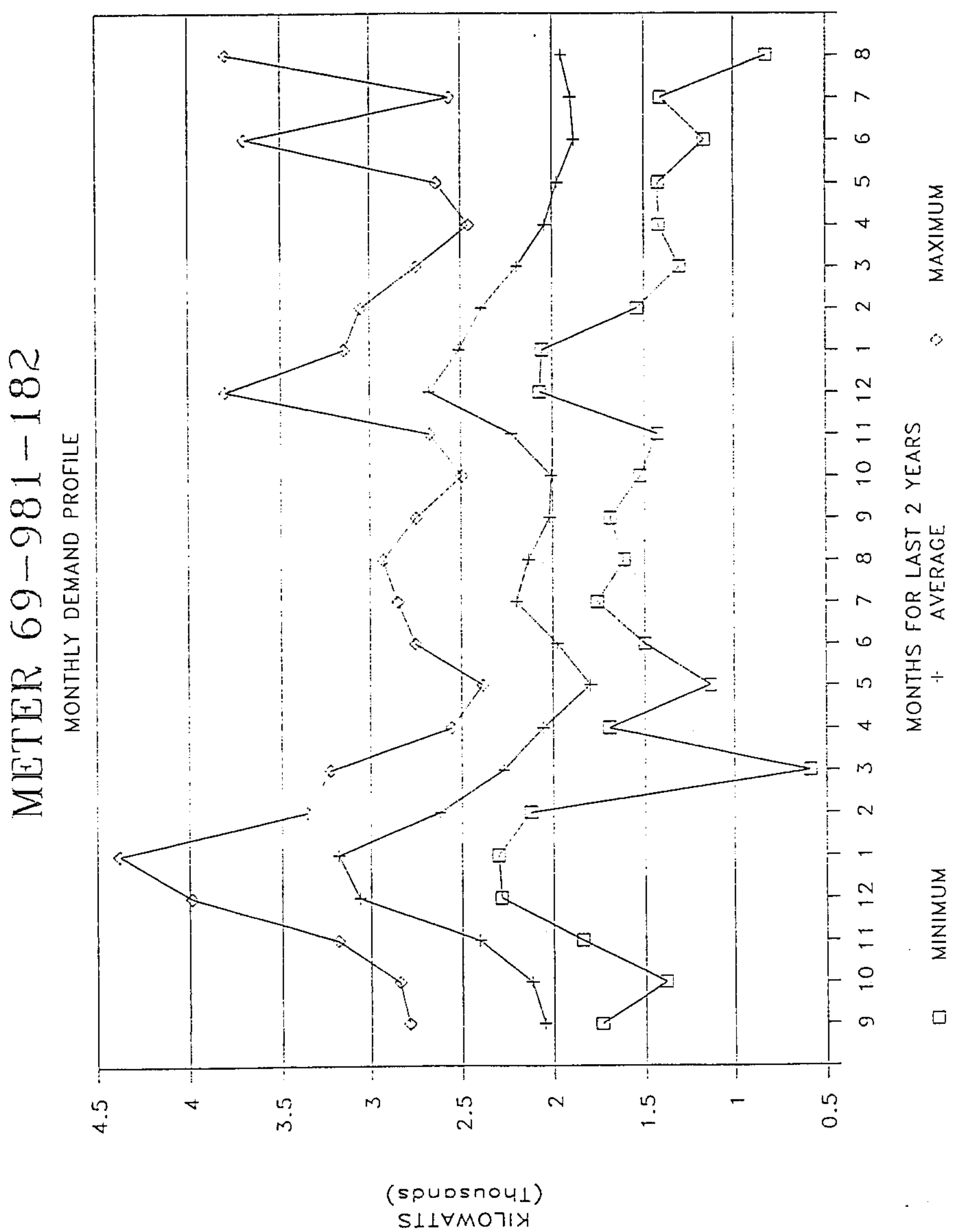


ELECTRICITY CONSUMPTION ANO COST REPORT

\begin{tabular}{|c|c|c|c|c|c|c|c|c|c|c|}
\hline Building & & & $251 \cdot 4$ & & & & & & & \\
\hline Service 6 & $\begin{array}{l}\text { Line, Brea } \\
\text { er Number }\end{array}$ & ker & $\begin{array}{l}\mathrm{C} 8.14, \mathrm{C} \times 44 \\
\text { Feeder }\end{array}$ & & & & & & & Automatic Data \\
\hline $\begin{array}{l}\text { Kew Meter } \\
\text { Data Logg }\end{array}$ & $\begin{array}{l}\text { Number } \\
\text { er Number }\end{array}$ & & $\begin{array}{l}90 \cdot 071-271 \\
084\end{array}$ & & Old Meter & Number & NA & & . & \\
\hline $\begin{array}{l}\text { Month } \\
\& \text { Year }\end{array}$ & $\begin{array}{l}\text { Percent } \\
\text { Capture }\end{array}$ & $\begin{array}{c}\text { Average } \\
\text { (XW) }\end{array}$ & $\begin{array}{c}\text { Monthly } \\
\text { Consump. } \\
\text { (KWH) }\end{array}$ & $\begin{array}{l}\text { Maximum } \\
(X H)\end{array}$ & $\begin{array}{l}\text { Minimum } \\
\text { (KW) }\end{array}$ & $\begin{array}{l}\text { Load } \\
\text { Factor }\end{array}$ & $\begin{array}{c}\text { Energy } \\
\text { Cost } \\
\text { (s) }\end{array}$ & $\begin{array}{c}\text { Demand } \\
\text { Cost } \\
\text { (\$) }\end{array}$ & $\begin{array}{l}\text { Total } \\
\text { Cost } \\
(\$)\end{array}$ & Corments \\
\hline $09 / 97$ & 99.9 & $1,413.6$ & $1,017,792$ & $1,942.2$ & 999.0 & 0.73 & $22,198.04$ & $4,678.76$ & $26,876.80$ & \\
\hline $10 / 97$ & 100.0 & $1,551.1$ & $1,154,018$ & $2,271.6$ & $1,085.4$ & 0.68 & $25,169.14$ & $5,472.28$ & $30,641.43$ & \\
\hline $11 / 97$ & 99.7 & $1,526.0$ & $1,386,720$ & $2,507.4$ & $1,360.8$ & 0.77 & $30,244.36$ & $6,040.33$ & $36,284.69$ & \\
\hline $12 / 97$ & 100.0 & $2,014.2$ & $1,498,565$ & $2,710.8$ & $1,474.2$ & 0.74 & $32,683.70$ & $6,530.32$ & $39,214.02$ & \\
\hline $01 / 98$ & 98.9 & $2,159.7$ & $1,605,817$ & $2,786.4$ & $1,530.0$ & 0.78 & $35,623.13$ & $6,712.44$ & $42,335.57$ & \\
\hline $02 / 98$ & 99.7 & $2,111.7$ & $1,419,056$ & $2,707.2$ & $1,580.4$ & 0.78 & $31,460.46$ & 6.521 .64 & $37,982.11$ & \\
\hline $03 / 98$ & 99.7 & 1.871 .8 & $1,407,499$ & $2,556,0$ & 0.0 & 0.74 & $31,204.26$ & $6,157.40$ & $37,361.66$ & Load Transferred. \\
\hline $04 / 98$ & 98.2 & $1,692.2$ & $1,218,384$ & $2,358.0$ & $1,279.8$ & 0.72 & $24,160.55$ & $5,680.42$ & $29,840.98$ & \\
\hline $05 / 98$ & 99.5 & $1,415.8$ & $1,054,097$ & $1,816.2$ & $1,162.8$ & 0.78 & $10,962.63$ & $4,375.23$ & $15,337.86$ & \\
\hline $06 / 98$ & 99.9 & $1,476,3$ & $1,062,836$ & $2,052.0$ & $1,209.6$ & 0.72 & 19.054 .53 & $4,943.27$ & $15,997.80$ & \\
\hline $07 / 98$ & 99.7 & $1,527.8$ & $1,136,683$ & $2,142.0$ & $1,060.2$ & 0.71 & $14,526.81$ & $5,160.08$ & 19.686 .89 & \\
\hline $08 / 98$ & 99.7 & $1,513.2$ & $1,125,821$ & $2,116.8$ & $1,146.6$ & 0.71 & $20,489.94$ & $5,099.37$ & $25,589.31$ & \\
\hline $09 / 98$ & 99.2 & $1,149.9$ & 827,928 & $2,070.0$ & 0.0 & 0.56 & $18,057.11$ & $4,985.63$ & $23,043.74$ & Load Transferred. \\
\hline $10 / 98$ & 99.5 & $1,601,3$ & $1,191,367$ & $2,282.4$ & $1,198.8$ & 0.70 & $25,983.72$ & $5,498.30$ & $39,482.02$ & \\
\hline $11 / 98$ & 99.3 & $1,955.4$ & $1,415,088$ & $2,638.8$ & $1,503.0$ & 0.74 & $30,863.07$ & $6,356.87$ & 37.219 .94 & \\
\hline $12 / 98$ & 99.3 & $2,441.0$ & $1,816,104$ & $3,299.4$ & $1,875.6$ & 0.74 & $39,609.23$ & $7,948.25$ & $47,557.48$ & \\
\hline $01 / 99$ & 99.9 & $2,320,9$ & $1,726,750$ & $3,137.4$ & $1,809.0$ & 0.74 & $38,282.04$ & $7,558.00$ & $45,840.04$ & \\
\hline $02 / 99$ & 99.7 & $2,217.0$ & $1,489,824$ & $3,007.8$ & $1,737.0$ & 0.74 & $33,029.40$ & $7,245.79$ & $40,275.19$ & \\
\hline $03 / 99$ & 99.2 & $1,957.1$ & $1,456,082$ & $2,958.2$ & $1,204.2$ & 0.65 & $32,281.35$ & $7,150.39$ & $39,439.74$ & \\
\hline $04 / 99$ & 99.7 & $1,695.1$ & $1,220,472$ & $2,453.4$ & $1,339.2$ & 0.69 & $24,201.95$ & $5,910.24$ & 30.112 .20 & \\
\hline $05 / 99$ & 99.9 & $i, 601.5$ & $1,191,516$ & $2,199.6$ & $1,281.6$ & $0.73^{\circ}$ & $12,391.77$ & $5,298.84$ & $17,690.60$ & \\
\hline $06 / 99$ & 99.6 & $1,481.0$ & $1,066,320$ & $2,116.8$ & 0.0 & 0.70 & $11,089.73$ & $5,099.37$ & $16,189.10$ & Load Transferred. \\
\hline $07 / 99$ & 99.9 & $1,561.9$ & $1,162,054$ & $2,534.4$ & $1,105.2$ & 0.62 & 14.851 .05 & $6,105.37$ & $20,956.41$ & \\
\hline $08 / 99$ & 94.5 & $1,655.2$ & $1,231,469$ & $2,176.2$ & 511.2 & 0.76 & $22,412.73$ & $5,242.47$ & $27,655.20$ & \\
\hline Average & 99.4 & $1,764.2$ & $1,286,807$ & $2,452.1$ & $1,143.9$ & 0.72 & $24,701.28$ & $5,907.97$ & $30,608.45$ & \\
\hline Maximum & 100.0 & $2,441.0$ & $1,816,104$ & $3,299.4$ & $1,875.6$ & 0.78 & $39,609.23$ & $7,948.25$ & $47,557,48$ & \\
\hline
\end{tabular}




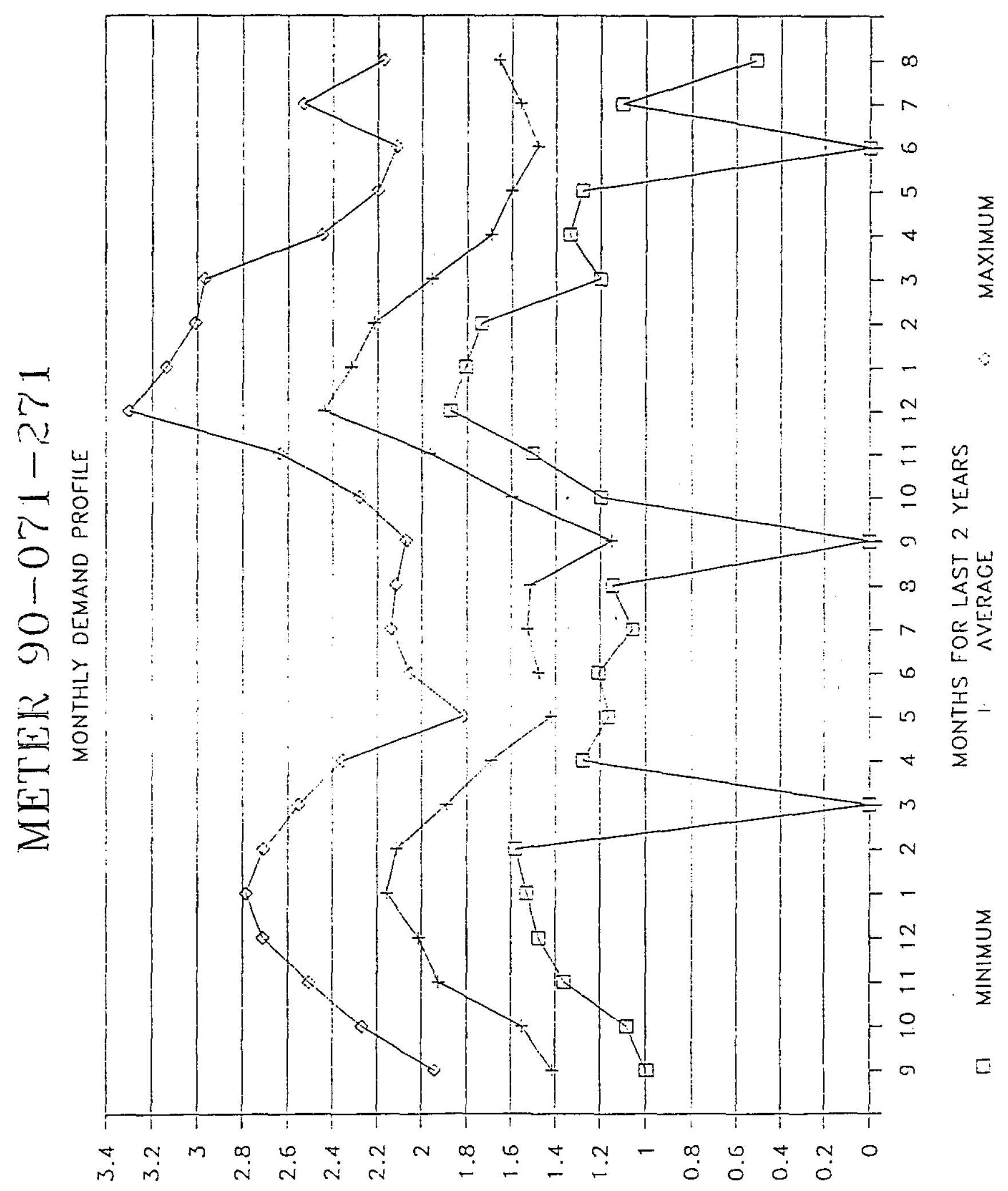

(spuosnoul)

SLIMOרו 


\section{ELECTRICITY CONSUMPTION AND COST REPORT}

\begin{tabular}{|c|c|c|c|c|c|c|c|c|c|c|}
\hline Building & & & $251 \cdot 4$ & & & & & & & \\
\hline Service & Line, Brea & ker) & $C 8-16, C 8 \times 6$ & & & & & & & Automatic Oata \\
\hline Transforn & er Number & & Feeder & & & & & & & \\
\hline New Meter & Number & & $90-071-275$ & & Old Meter & Number & $\mathrm{NA}$ & & & \\
\hline Data Logs & er Number & & 084 & & & & & & & \\
\hline $\begin{array}{l}\text { Month } \\
\& \text { Year }\end{array}$ & $\begin{array}{l}\text { Percent } \\
\text { Capture }\end{array}$ & $\begin{array}{c}\text { Average } \\
(K W)\end{array}$ & $\begin{array}{l}\text { Monthly } \\
\text { Consump. } \\
\text { (KWH) }\end{array}$ & $\begin{array}{l}\text { Maximum } \\
(X H)\end{array}$ & $\begin{array}{l}\text { Minimum } \\
\text { (KW) }\end{array}$ & $\begin{array}{l}\text { Load } \\
\text { Factor }\end{array}$ & $\begin{array}{c}\text { Energy } \\
\text { Cost } \\
\text { (s) }\end{array}$ & $\begin{array}{c}\text { Demand } \\
\text { Cost } \\
\text { (\$) }\end{array}$ & $\begin{array}{l}\text { Total } \\
\text { Cost } \\
(s)\end{array}$ & Coments \\
\hline $09 / 97$ & 99.9 & $2,977.3$ & $2,143,655$ & $3,972.6$ & $1,999.8$ & 0.75 & $46,753.14$ & $9,569.99$ & $56,323.13$ & \\
\hline $10 / 97$ & 100.0 & $2,857.8$ & $2,126,203$ & $4,566.6$ & $1,789.2$ & 0.63 & $46,372.49$ & $11,000.94$ & $57,373.43$ & \\
\hline $11 / 97$ & 99.7 & $3,341.9$ & $2,406,168$ & $4,312.8$ & $2,142.0$ & 0.77 & $52,478.52$ & $10,389.54$ & $62,868.06$ & \\
\hline $12 / 97$ & 100.0 & $3,533.1$ & $2,628,626$ & $4,685.4$ & $2,255.4$ & 0.75 & $57,330.34$ & $11,287.13$ & $68,617.47$ & \\
\hline $01 / 98$ & 98.9 & $3,197.6$ & $2,379,014$ & $4,806.0$ & $1,827.0$ & 0.67 & $52,742.75$ & $11,577.65$ & $64,320.40$ & \\
\hline $02 / 98$ & 99.7 & $3,177.7$ & $2,135,414$ & $4,109.4$ & $2,044.8$ & 0.77 & $47,342.14$ & $9,899.54$ & $57,241.68$ & \\
\hline $03 / 98$ & 99.7 & $3,048.4$ & $2,268,010$ & $3,922.2$ & 0.0 & 0.78 & $50,281.77$ & $9,448.58$ & $59,730.35$ & Load Transferred. \\
\hline $04 / 98$ & 98.2 & $2,723.6$ & $1,960,992$ & $3,447.0$ & $1,476.0$ & 0.79 & $38,886.47$ & $8,303.82$ & $47,190.29$ & \\
\hline $05 / 98$ & 99.5 & $2,664.8$ & $1,982,611$ & $3,198.6$ & 1.477 .8 & 0.83 & $20,619.16$ & $7,705.43$ & $28,324.58$ & \\
\hline $06 / 98$ & 99.9 & $2,647.8$ & $1,906,416$ & $3,454.2$ & $1,386.0$ & 0.77 & $19,826.73$ & $8,321.17$ & $28,147.89$ & \\
\hline $07 / 98$ & 99.7 & $2,876.6$ & $2,140,190$ & $3,643.2$ & $1,522.8$ & 0.79 & $27,351.63$ & $8,776.47$ & $36,128.10$ & \\
\hline $08 / 98$ & 99.7 & $2,449.8$ & $1,822,651$ & $3,587.4$ & $1,449.0$ & 0.68 & $33,172.25$ & $8,642.05$ & $49,814.30$ & \\
\hline $09 / 98$ & 99.2 & $1,978.9$ & $1,424,803$ & $3,3: 0.2$ & 0.0 & 0.60 & $31,075.06$ & $7,974.27$ & $39,049.33$ & Load Transferred. \\
\hline $10 / 98$ & 99.5 & $2,636.2$ & $1,961,333$ & $3,540.6$ & $1,405.8$ & 0.74 & $42,776.67$ & $8,529.31$ & $51,305.97$ & \\
\hline $11 / 98$ & 99.3 & $2,906.4$ & $2,092,608$ & $3,753.0$ & $1,548.0$ & 0.77 & $45,639.78$ & $9,040.98$ & $54,680.76$ & \\
\hline $12 / 98$ & 99.3 & $3,001.7$ & $2,233,265$ & $4,024.8$ & $1,695.6$ & 0.75 & $48,707.5 i$ & $9,695.74$ & $58,403.25$ & \\
\hline $01 / 99$ & 99.9 & $2,873.7$ & $2,138,033$ & $3,821.4$ & $1,549.8$ & 0.75 & $47,400.19$ & $9,205.75$ & $56,605.94$ & \\
\hline $02 / 99$ & 99.7 & $3,037.3$ & $2,041,065$ & $3,920.4$ & $1,827.0$ & 0.77 & $45,250.42$ & 9.444 .24 & $54,694.67$ & \\
\hline $03 / 99$ & 99.2 & $2,311.1$ & $1,719,458$ & $3,330.0$ & $1,450.8$ & 0.69 & $38,120.39$ & $8,021.97$ & $45,142.36$ & \\
\hline $04 / 99$ & 99.7 & $2,652.7$ & $1,909,944$ & 3.708 .0 & $1,843.2$ & 0.72 & $37,874.19$ & $8,932.57$ & $45,806.76$ & \\
\hline $05 / 99$ & 99.9 & $2,210.0$ & $1,6 \div 4,2 \div 0$ & $2,921,4$ & $1,318.4$ & 0.76 & $17,100.10$ & $7,037.65$ & $24,137.75$ & \\
\hline $06 / 99$ & 99.6 & $2,107.5$ & $1,517,400$ & $2,756.6$ & $1,409.4$ & 0.76 & $15,780.96$ & $6,664.74$ & $22,445.70$ & \\
\hline $07 / 99$ & 99.9 & $2,609.2$ & $1,941,245$ & $3,283.2$ & $1,263.6$ & 0.79 & $24,809.11$ & $7,909.23$ & $32,718.34$ & \\
\hline $08 / 99$ & 94.5 & $1,940.8$ & $1,443,955$ & $3,17 \Sigma .2$ & $1,094.4$ & 0.61 & $26,279.98$ & $7,649.05$ & $33,929.04$ & \\
\hline Average & 99.4 & $2,740.1$ & $1,998,638$ & $3,719.2$ & $1,490.7$ & 0.74 & $38,082.16$ & $8,959.49$ & $47,041.65$ & \\
\hline Maximum & 100.0 & $3,533.1$ & $2,628,626$ & $4,806.0$ & $2,255.4$ & 0.83 & $57,330.34$ & $11,577.65$ & $68,697.47$ & \\
\hline
\end{tabular}




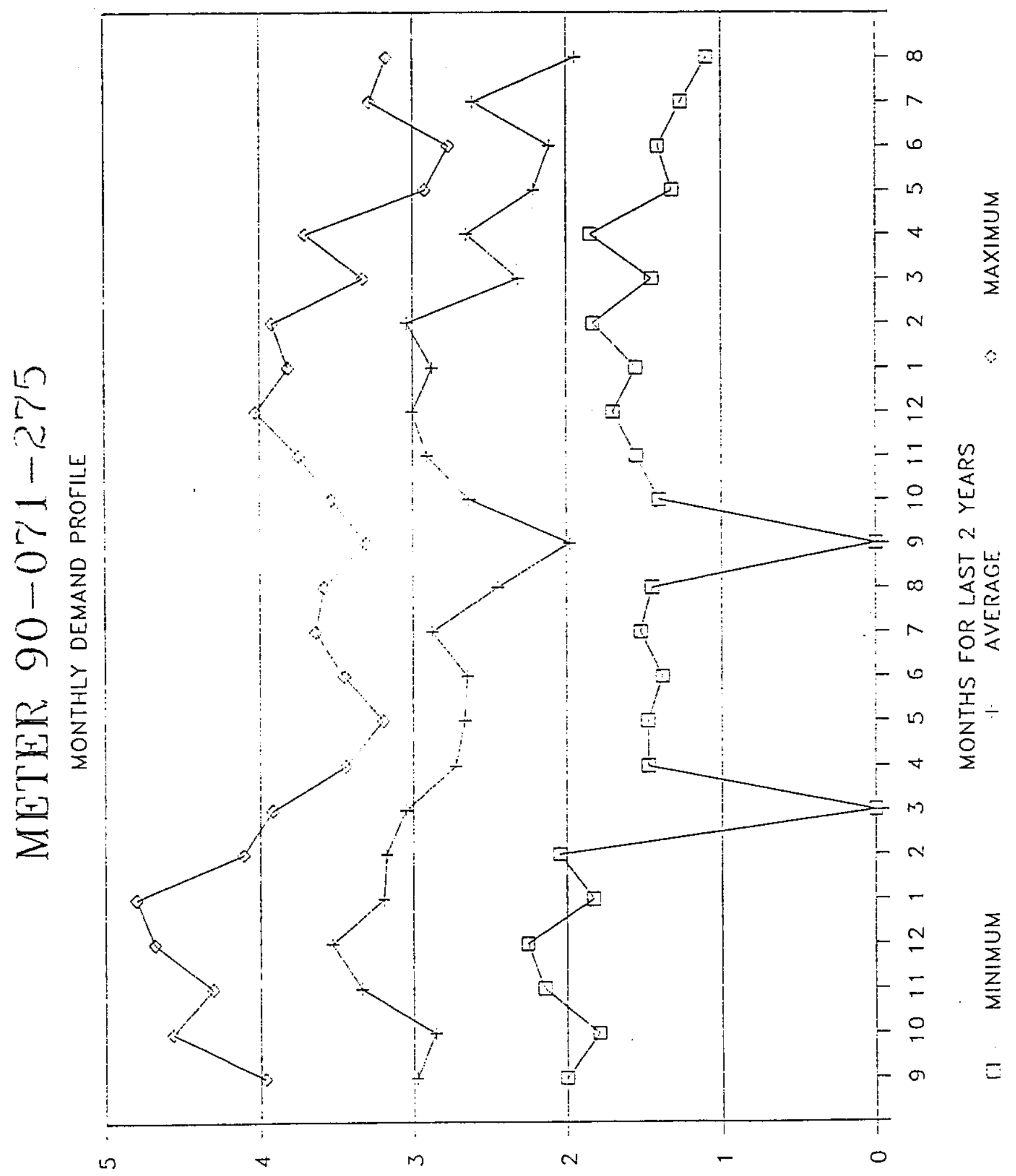

(spuosnoul)

S1LVMOTIX 
RPP- 5228

REVISION 0

ELECTRICITY CONSUMPTION AND COST REPORT

$\begin{array}{lll}\text { Building } & 251-W & \\ \text { Service (Line,Breaker) } & C 8 \cdot L 8, \text { C8X8 } & \\ \text { Transformer Number } & \text { Feeder } & \\ \text { New Meter Number } & 90-071 \cdot 278 & \text { Old Meter Nimber } \\ \text { Data Logger Number } & 084 & \end{array}$

\begin{tabular}{|c|c|c|c|c|c|c|c|c|c|c|}
\hline $\begin{array}{l}\text { Month } \\
\& \text { Year }\end{array}$ & $\begin{array}{l}\text { Percent } \\
\text { Capture }\end{array}$ & $\begin{array}{c}\text { Average } \\
\text { (KW) }\end{array}$ & $\begin{array}{c}\text { Monthly } \\
\text { Consump. } \\
\text { (XWH) }\end{array}$ & $\begin{array}{l}\text { Maximum } \\
(K H)\end{array}$ & $\begin{array}{l}\text { Minimum } \\
(\mathrm{KW})\end{array}$ & $\begin{array}{l}\text { Load } \\
\text { gactor }\end{array}$ & $\begin{array}{c}\text { Energy } \\
\text { cost } \\
\text { (\$) }\end{array}$ & $\begin{array}{c}\text { Demand } \\
\text { Cost } \\
\text { (\$) }\end{array}$ & $\begin{array}{l}\text { Total } \\
\text { Cost } \\
\text { (5) }\end{array}$ & Comments \\
\hline $09 / 97$ & 99.9 & 143.6 & 103,392 & 181.8 & 18.8 & 0.79 & $2,254.98$ & 437.95 & $2,692.94$ & \\
\hline $10 / 97$ & 100.0 & 152.2 & 113,237 & $2,208.6$ & 45.0 & 0.07 & $2,469.69$ & $5,320.52$ & $7,790.21$ & Load Combined. \\
\hline $11 / 97$ & 99.7 & 71.3 & 51,336 & 156.6 & 16.4 & 0.66 & $1,119.64$ & 377.25 & $1,496.89$ & \\
\hline $12 / 97$ & 100.0 & 53.8 & 40,027 & 144.0 & 14.4 & 0.37 & 872.99 & 346.90 & $1,219.89$ & \\
\hline $01 / 98$ & 98.9 & 176.7 & 131,465 & 226.8 & 127.8 & 0.78 & $2,914.57$ & 546.36 & $3,460.94$ & \\
\hline $02 / 98$ & 99.7 & 120.8 & 81,245 & 178.2 & 12.6 & 0.68 & $1,801.20$ & 429.28 & $2,230.48$ & \\
\hline $03 / 98$ & 89.7 & 60.5 & 45,012 & 3.173 .4 & 12.6 & 0.02 & 997.92 & $7,644.72$ & $8,642,64$ & Load Combined. \\
\hline $04 / 98$ & 98.2 & 110.9 & 79,848 & 172.8 & 12.6 & 0.64 & $1,583.39$ & 416.28 & $1,999.66$ & \\
\hline $05 / 98$ & 99.5 & 63.8 & 47,457 & 154.8 & 12.6 & 0.41 & 493.66 & 372.91 & 866.57 & \\
\hline $06 / 98$ & 99.9 & 113.3 & 81,576 & 154.8 & 12.6 & 0.73 & 848.39 & 372.91 & $1,221.30$ & \\
\hline $07 / 98$ & 99.7 & 76.6 & 56,990 & 154.8 & 12.6 & 0.49 & 728.34 & 372.91 & $1,101.25$ & \\
\hline $08 / 98$ & 99.7 & 129.5 & 95,348 & 154.8 & 12.6 & 0.84 & $1,753.53$ & 372.91 & $2,126.45$ & \\
\hline $09 / 98$ & 99.2 & 81.3 & 58,536 & 154.8 & 0.0 & 0.53 & $1,275.67$ & 372.91 & $1,649.58$ & Load Iransferred. \\
\hline $10 / 98$ & 99.5 & 77.3 & $57,51 i$ & 156.6 & 12.6 & 0.49 & $1,254.32$ & 377.25 & $1,631.57$ & \\
\hline $11 / 98$ & 99.3 & 543.1 & 394,632 & $2,311,2$ & 57.5 & 0.24 & $8,605.92$ & $5,567.68$ & $14,174.60$ & Load Combined. \\
\hline $12 / 98$ & 99.3 & $1,063.9$ & 791,542 & $2,719.8$ & 0.0 & 0.39 & $17,263.52$ & $6,552.00$ & $23,815.52$ & Load Combined. \\
\hline $01 / 99$ & 99.9 & 177.4 & 131,986 & 196.2 & $15 \div .8$ & 0.90 & $2,926.12$ & 472.65 & $3,398.77$ & \\
\hline $02 / 99$ & 99.7 & 170.8 & 114,773 & 192.5 & $1<9.4$ & 0.89 & $2,544.62$ & 463.97 & 3.008 .59 & \\
\hline $03 / 99$ & 99.2 & 164.9 & 122.685 & 187.2 & 147.6 & 0.88 & $2,719.94$ & 450.96 & $3,170.90$ & \\
\hline $04 / 99$ & 99.7 & 150.4 & 108,283 & 187.2 & $i 02.6$ & 0.80 & $2,147.35$ & 450.96 & $2,598.32$ & \\
\hline $05 / 99$ & 99.9 & 145.7 & 108,401 & 421.1 & 120.6 & 0.35 & $1,127.37$ & $1,014.43$ & $2,141.80$ & \\
\hline $06 / 99$ & 99.7 & 132.3 & 95,256 & 153.0 & 90.0 & 0.85 & 990.66 & 368.58 & 1.359 .24 & \\
\hline $07 / 99$ & 97.9 & 130.0 & 95,720 & 167.6 & 117.0 & 0.88 & $1,236.08$ & 355.57 & $1,591.65$ & \\
\hline $08 / 99$ & 94.5 & 136.5 & 101,556 & 151.2 & 3.6 & 0.90 & $1,848.32$ & 364.24 & $2,212.56$ & \\
\hline Average & 99.4 & 177.2 & 129,576 & 585.0 & 52.0 & 0.30 & $2,574.17$ & $1,409.25$ & $3,983.43$ & \\
\hline Maximum & 100.0 & $1,063,9$ & 791,542 & $3,173,4$ & 154.8 & 0.90 & $17,263.52$ & $7,644.72$ & $23,815.52$ & \\
\hline
\end{tabular}




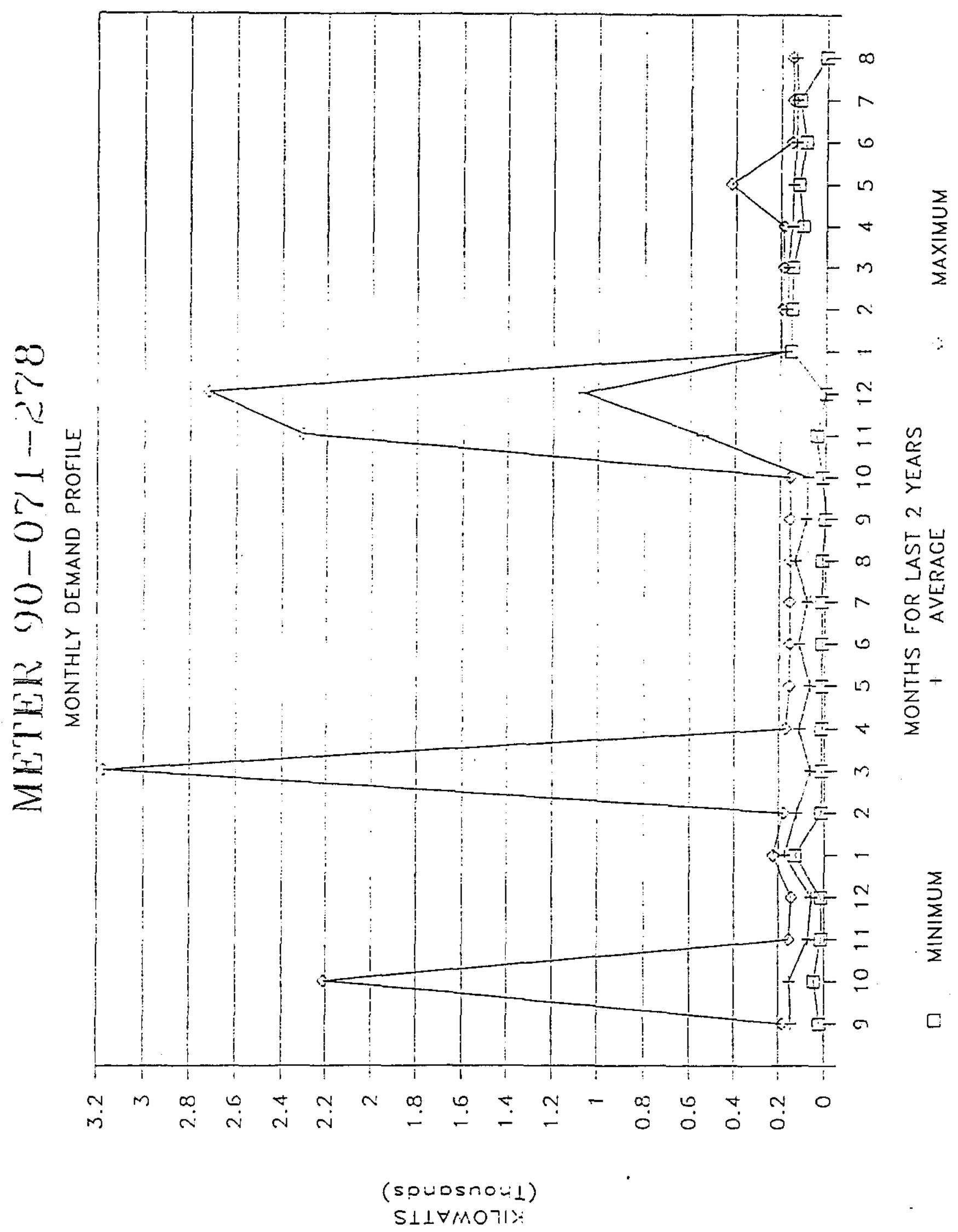


RPP-5228

REVISION 0

Appendix C

Scope of Work

C-1 
Waste Feed Delivery Phase I

Electrical Power Study

\subsection{Objoctive}

The seller shall perform the studies necessary to assess the electrical power requirements for continued afe trorage of waste in the SSTs and any additional power required for rerrieving waste for Phase I Waste Feed Delivery (WFD). Phase 1 includes both Plase 18 and 18 prime.

\subsection{Scope of Work}

This task consists of the following activities:

1. Assess the electrical power required for continued sefe storage of waste in the double-shell tanks. This assessment will be performed on a farm by farm basis.

2. Assess the electrical power required to retrieve paste from the DSTs for Phase 1 WFD. This assesconent will assime the simulteneous operation of 2,300HP mixer pomps per tank farm and the one concurrent transfer of waste from or within any 2 farms in the 200 East Area and from the SY farm in the 200 West Ares The assessments pill be estimates of additional powrer required for support systems.

3. Assess the eiectrical power required to support the retrieval of waste from a SST.

4. Assess the capability of the electrical system to satisfy the electrical power requirements for continued safe storage of waste in both the SSTS and DSTs in the 200 East area concurrent with DST waste retrieval per activity 2 and retrieval from one SST from A., AX-, or C-Fam. Assume SST retrieval directly into a DST in the AY.Farm. The electrical power estimate shall include power within the DST Farms for transferring superratant to the SST. The assessment shall identify clectrical powter requirements for cach tank farm, a proposed source of existing source of power, and any new electrical power capability that may be needed Estimates of SST safe storage electrical power requirements Fere provided in a previous saudy that will be provided.

5. Assess the capability of the eletrical system to satisfy the eloctrical power requirements for continued safe storage of waste in both the SSTs and DSTs in the 200 West area concturent with DST waste retricval per activity 2 and the simultaneous retrieval from toro SSTs from S-, SX., or U-Farm. Assume SST retrieval directly into a DST in the SY.Farm. The electrical power estimate shall include power within the DST Farms for transferring supernatam to the SST. The assessment shall identify electrical power requirements for each tank farm, a proposed source of existing source of power, and any new electrical power capability that be needed. Estimates of SST safe storage electrical power requirements were provided in a previous study that will be provided.

\subsection{Deliverables}

Report documenting electrical power requirements

Repor documenting the assessment of the systems ability to provide the power.

Draft reports to be reviewed by NHC.

Final reports delivered to NHC for approval on September 10, 1999.

\subsection{Feriod of Performance}

July 28, 1999 through September 10, 1999.' Task point of contact is Charles E. Grenard, Namatec Fanford Corp., 376-3550. 
Distribution Continuation Sheet for EDT 628254

Reason for

transmittal MI-SN

Plant Engineering

Pete Hopkins

$3 \quad \mathrm{R} 2-58$

Equipment engineering manager

Electrical

Al Friberg

Mazen Al-Wazani

$3 \quad \mathrm{R} 1-56$

$3 \quad \mathrm{R} 1-56$

DST Engineering manager

Dan Baide

$3 \quad$ S5-05

Electrical COG

John Wells

S5-05

SST Engineering manager

Rich Larson

T4-07

Projects

Kitty Bryan

$\mathrm{R} 2-58$

W-211

Steve Briggs

S2-48

W-211 manager

W-314

John Van Beek

S2-48

Bob Bevins

R3-25

Jack Lentsch

R3-25

Tom May

R3-73

W-521

W-314 manager

Greg Mclellan

S2-48

Other reviewers

DYN engineering services

Mike Hache

Gary Duncan

Ryan Dodd

Retrieval Support Ops mgr

Industrial Safety

Jeff Ranschau

Integration Services mgr

Nuclear Safety

Susan Alexander

Peter Smith

Richard Pierson

Dave Hammond

Kathy Tollefson

Brad Erlandson

John Bores

Katie White

Phil Brackenbury

Alan Carlson

Charles Grenard

Tom Conrads

Greg Deweese

3

S2-12

3

R3-73

R3-73

S7-07

S7-86

S7-01

S6-14

R1-49

R1-51

R1-51

R2-89

USQs

Program Engineering

Retrieval Engineering

Project Definition

Project Definition manager

Waste Feed Delivery

Warren Thompson

S5-13

R3-73

R3-73

R3-73

R3-73

R3-73

R3-73 